\title{
Solution speciation and human serum protein binding of indium(III) complexes of 8-hydroxyquinoline, deferiprone and maltol
}

\author{
Orsolya Dömötör ${ }^{1,2}$ (1) $\cdot$ Bernhard K. Keppler ${ }^{3} \cdot$ Éva A. Enyedy $^{1,2}$ (])
}

Received: 22 November 2021 / Accepted: 18 February 2022 / Published online: 3 March 2022

(c) The Author(s) 2022

\begin{abstract}
Solution speciation and serum protein binding of selected In(III) complexes bearing $O, O$ and $O, N$ donor sets were studied to provide comparative data for In(III) and analogous Ga(III) complexes. Aqueous stability of the In(III) complexes of maltol, deferiprone, 8-hydroxyquinoline (HQ) and 8-hydroxyquinoline-5-sulfonate (HQS) was characterized by a combined pH-potentiometric and UV-visible spectrophotometric approach. Formation of mono, bis and tris-ligand complexes was observed. The tris-ligand complexes of $\mathrm{HQ}\left(\mathrm{InQ}_{3}\right)$ and deferiprone $\left(\mathrm{InD}_{3}\right)$ are present in solution in ca. $90 \%$ at $10 \mu \mathrm{M}$ concentration at $\mathrm{pH}=7.4$, while the tris-maltolato complex $\left(\mathrm{InM}_{3}\right)$ displays insufficient stability under these conditions. Binding towards human serum albumin (HSA) and (apo)transferrin ((apo)Tf) of $\mathrm{InQ}_{3}, \mathrm{InD}_{3}$ and $\mathrm{InM}_{3}$ complexes and $\mathrm{Ga}$ (III) analogue of $\operatorname{InQ}_{3}\left(\mathrm{GaQ}_{3}\right)$ together with $\mathrm{InCl}_{3}$ was investigated by a panel of methods: steady-state and time-resolved spectrofluorometry, $\mathrm{UV}$-visible spectrophotometry and membrane ultrafiltration. Moderate binding of $\operatorname{InQ}_{3}$ to $\mathrm{HSA}$ was found $\left(\log K^{\prime}=5.0-5.1\right)$. $\mathrm{InD}_{3}$ binds to HSA to a much lower extent in comparison to $\mathrm{InQ}_{3}$. ApoTf is able to displace HQ, deferiprone and maltol effectively from their $\mathrm{In}(\mathrm{III})$ complexes. Protein binding of non-dissociated $\operatorname{InQ}_{3}$ was also observed at high complex-toapoTf ratios. Studies conducted with the $\mathrm{InQ}_{3} / \mathrm{GaQ}_{3}-\mathrm{HSA}$ - Tf ternary systems revealed the more pronounced Tf binding of In(III) via ligand release, while the original $\mathrm{GaQ}_{3}$ scaffold is preferably retained upon protein interactions and significant albumin binding occurs. Significant dissociation of $\mathrm{InQ}_{3}$ was detected in human blood serum as well.
\end{abstract}

\section{Graphical abstract}

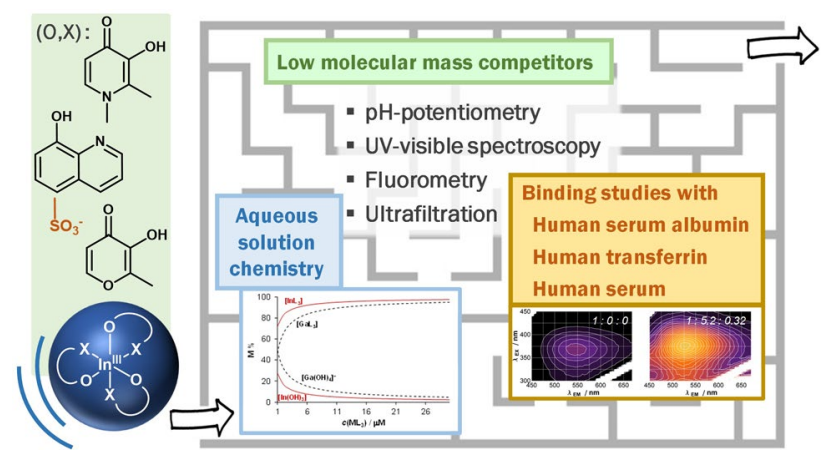

Keywords Stability constant $\cdot$ Albumin $\cdot$ Transferrin $\cdot$ Fluorescence $\cdot$ Ultrafiltration

\section{Abbreviations}

apoTf Apotransferrin

deferiprone 3-Hydroxy-1,2-dimethylpyridin-4(1H)-one

Orsolya Dömötör

domotor.o@chem.u-szeged.hu

Extended author information available on the last page of the article
$\mathrm{GaM}_{3} \quad$ Tris(3-Hydroxy-2-methyl-4H-pyran-4onato)gallium(III)

$\mathrm{GaQ}_{3} \quad$ Tris(8-Quinolinolato)gallium(III)

HEPES 4-(2-Hydroxyethyl)-1-piperazineethanesulfonic acid

HMM High molecular mass

HQ 8-Hydroxyquinoline 


$\begin{array}{ll}\text { HQS } & \begin{array}{l}\text { 8-Hydroyquinoline-5-sulfonate } \\ \text { HSA }\end{array} \\ \mathrm{InD}_{3} & \begin{array}{l}\text { Human serum albumin } \\ \text { Tris(3-Hydroxy-2-methyl-4H-pyran-4- } \\ \text { onato)indium(III) } \\ \text { Tris(3-Hydroxy-2-methyl-4H-pyran-4- } \\ \text { onato)indium(III) }\end{array} \\ \mathrm{InM}_{3} & \text { Tris(8-Quinolinolato)indium(III) } \\ \mathrm{InQ}_{3} & \text { Low molecular mass } \\ \mathrm{LMM} & \text { 3-Hydroxy-2-methyl-4H-pyran-4-one } \\ \text { maltol } & \text { Transferrin } \\ \text { Tf } & \text { UV-visible }\end{array}$

\section{Introduction}

Numerous In(III) and Ga(III) complexes are applied as pharmaceutical agents in connection with their diagnostic and therapeutic properties. Indium-based agents containing ${ }^{113 \mathrm{~m}} \mathrm{In}(\mathrm{III})$ or ${ }^{111} \mathrm{In}(\mathrm{III})$ have been used in diagnostic nuclear medicine for decades [1-3]. A number of In(III)-chelates have been tested for the selective delivery of ${ }^{111} \operatorname{In}(\mathrm{III})$ to various tissues, the tris-ligand complex of 8-hydroxyquinoline (HQ) is the only indium containing product currently approved by the FDA for the detection and diagnosis of infections and inflammatory lesions [2, 4]. This HQ complex is not directly injected in the blood, extensive serum protein binding of In(III) necessitates standardized procedures where cellular elements of the blood (principally leukocytes) are separated and labelled with the complex outside the patient's body and then returned to the circulatory system $[2,5]$. The HQ scaffold is found in various metal complexes (e.g. $\mathrm{Cu}(\mathrm{II}), \mathrm{Fe}(\mathrm{III})$ or ${ }^{89} \mathrm{Zr}(\mathrm{IV})$ ) being developed for cancer therapy or diagnostics $[6,7]$. Recently anticancer activity of In(III) complexes of thiosemicarbazones and 3-hydroxy2-methyl-4H-pyran-4-one (maltol) was reported on HepG2 $\left(\mathrm{IC}_{50}=3.5 \mu \mathrm{M}\right)$ and MDA-MB-231 $\left(\mathrm{IC}_{50}=32 \mu \mathrm{M}\right)$ cell lines, respectively $[8,9]$ and numerous $\operatorname{In}(\mathrm{III})$-porphyrin complexes were tested for use in photodynamic therapy as well showing promising results $[10,11]$.

Radiopharmaceuticals containing ${ }^{67} \mathrm{Ga}$ and ${ }^{68} \mathrm{Ga}$ isotopes are used in imaging for some cancer types, infections and inflammatory diseases [12]. Besides, citrate stabilized salt $\mathrm{Ga}\left(\mathrm{NO}_{3}\right)_{3}\left(\mathrm{Ganite}^{\mathrm{TM}}\right)$ is a clinically approved formulation for the treatment of cancer-related hypercalcaemia [13]. Tris (8-hydroxyquinolinato) $\mathrm{Ga}$ (III) $\left(\mathrm{GaQ}_{3}\right.$, often referred as $\mathrm{KP} 46$ in the literature) and tris(maltolato) $\mathrm{Ga}$ (III) $\left(\mathrm{GaM}_{3}\right)$ are orally active antitumor metallodrugs recently undergone clinical trials $[14,15]$. According to the hypothesized mechanism of action of $\mathrm{GaM}_{3}$, Tf-receptor mediated uptake of $\mathrm{Ga}$ (III) takes place, and it inhibits the ribonucleotide reductase enzyme [12]. In the case of $\mathrm{GaQ}_{3}$, Tf-receptor independent transport process is suggested and the complex activates a variety of mechanisms and pathways resulting in apoptotic cell death [16, 17].

Transferrin (Tf) is the most significant In(III) binding protein in blood serum and it is thought to compete effectively with chelate forming ligands like citrate, nitrilotriacetic acid (NTA), thioglycolic acid or HQ for the binding of In(III) ions [1, 18-21]. Ga(III) can bind to Tf as well, at the same time in vitro investigations conducted in our research group pointed out the impact of the chelate forming ligand on the competition between the ligand an this protein for $\mathrm{Ga}$ (III). Tf binding of $\mathrm{Ga}(\mathrm{III})$ predominates in the case of the less stable tris-maltolato complex and the original complex dissociates, while this process is less significant for the more stable $\mathrm{GaQ}_{3}$ [22]. Another difference is, that the In(III)-Tf adduct can bind to the Tf-receptors of the cell membrane, however, in contrast to $\mathrm{Ga}$ (III)-Tf, cannot be internalized by cells [23]. This form of In(III) is not available for cellular uptake but can reach possible use in monitoring of vascular permeability [20, 23, 24].

There are some studies dedicated to the Tf binding of In(III) complexes, while thermodynamic interpretations of the observations are scarcely provided, and interaction with other serum components (e.g. low molecular mass (LMM) constituents of blood or HSA) is rarely considered [18, 20, $23,25,26]$. The Tf binding of In(III) ion was thoroughly investigated by Harris et al. and Kulprathipanja et al. via ligand competition studies, where the competitor ligand was NTA and EDTA, respectively $[18,26]$. At the same time, the In(III)-Tf binding constants determined by the two research groups differ in more than 10 orders of magnitude. The possible albumin binding of In(III) complexes was not reported yet, although in the case of $\mathrm{GaQ}_{3}$ it was found, that the non-dissociated complex preferably binds to HSA under physiological conditions [22].

The available literature refers to somewhat different serum speciation of $\mathrm{Ga}$ (III) and In(III) complexes, which we found worth to investigate in more detail. In this work, our aim is to provide a detailed study on the serum speciation of a group of tris-ligand In(III) complexes, and compare these results to that of $\mathrm{Ga}(\mathrm{III})$ analogues. Therefore, we report the solution equilibria of In(III) complexes of HQ, 8-hydroxyqionoline-5-sulfonate (HQS), 3-hydroxy-1,2-dimethylpyridin-4(1H)-one (deferiprone) and maltol (see Chart 1 for the structures). Their stability is compared to that of the analogous $\mathrm{Ga}(\mathrm{III})$ complexes. Interaction of the tris-ligand complexes with LMM serum components such as citrate, oxalate and phosphate, and binding towards serum proteins Tf and HSA is investigated as well. Protein binding of the respective complexes was followed in binary and ternary systems and in blood serum by techniques such as steadystate and time-resolved fluorometry, UV-visible (UV-vis) spectrophotometry and membrane ultrafiltration-UV-vis 


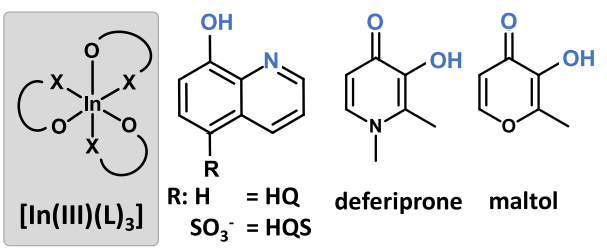

Chart 1 General structure of the tris-ligand In(III) complexes and chemical structure and abbreviations of the bidentate ligands 8-hydroxyquinoline (HQ), 8-hydroyquinoline-5-sulfonate (HQS), 3-hydroxy-1,2-dimethylpyridin-4(1H)-one (deferiprone) and 3-hydroxy-2-methyl-4H-pyran-4-one (maltol)

to characterize the binding events and to provide a semiquantitative description of the systems studied.

\section{Results and discussion}

\section{Solution stability of In(III) complexes of HQ, HQS and maltol}

To characterize the solution stability of the In(III) complexes, pH-potentiometric and UV-vis spectrophotometric titrations were performed in water in the presence of $0.20 \mathrm{M}$ chloride ions. However, stability constants for the HQ complexes could be obtained only by the latter method due to their much worse water solubility compared to the other compounds. HQS was involved as a water-soluble analogue of HQ bearing identical coordination mode. Stability constants of deferiprone were also determined by both methods in the present work to validate our experimental setup and data treatment, since the In(III) - deferiprone system was already characterized by Orvig and collaborators [27]. The hydrolysis of In(III) and its interaction with chloride ions were taken into consideration, and stability constants of the hydoxido and chlorido complexes [28] were utilized for our calculations. As a first step, the proton dissociation constants $\left(K_{\mathrm{a}}\right)$ were determined for the ligands (Table 1$)$ showing good agreement with the previously published data (see Table 1) [29-31]. The overall stability constants obtained for the octahedral In(III)-deferiprone complexes by both methods (Table 1) are fairly similar to those reported at $150 \mathrm{mM}$ $\mathrm{NaCl}$ [27]. As deferiprone, maltol, the other $O, O$-donor bearing ligand, also forms mono, bis and tris-ligand complexes; although they possess significantly lower $\log \beta$ values (Table 1) as it was observed for other metal ions such as $\mathrm{Ga}(\mathrm{III})$ [27, 29], $\mathrm{Fe}(\mathrm{III})[33,34]$ or $\mathrm{Zn}(\mathrm{II})$ [31]. Complexes with the same stoichiometry were also formed with the $\mathrm{O}, \mathrm{N}$ donor containing HQS (Table 1). Notably, the determined overall stability constants obtained for the In(III) complexes of deferiprone, maltol and HQS by the two methods represent acceptable agreement. Stability constants for the HQ complexes (Table 1) were determined by the deconvolution of UV-vis spectra recorded at various $\mathrm{pH}$ values (Fig. 1a), and the computed molar absorbance spectra for the individual ligand and complex species are shown in Fig. 1b. Due to the lack of d-d or charge transfer bands, the molar absorbance spectra of the complexes represent similar $\lambda_{\max }$ values to that of the completely deprotonated form of the ligand;
Table 1 Logarithm of overall stability constants $\log \beta$ for In(III) complexes formed with deferiprone, maltol, HQ and HQS with the $\mathrm{p} K_{\mathrm{a}}$ values of the ligands. ${ }^{\text {a }}(\mathrm{L}$ is the completely deprotonated form of the ligands.) $\mathrm{pM}^{*}$ $\left(-\log \left([\mathrm{M}]+\left[\mathrm{M}(\mathrm{OH})_{(1-4)}\right]\right)\right)^{\mathrm{b}}$ were computed at $\mathrm{pH} 7.4$ at $1 \mu \mathrm{M} \mathrm{In}(\mathrm{III})$ or $\mathrm{Ga}$ (III) and $10 \mu \mathrm{M}$ ligand concentrations. (Charges of the various species are omitted for clarity.) $\left\{T=25.0^{\circ} \mathrm{C}, I=0.20 \mathrm{M}(\mathrm{KCl})\right\}$

\begin{tabular}{llllll}
\hline & Method & Deferiprone & Maltol & HQS & HQ \\
\hline $\mathrm{p} K_{\mathrm{a}}\left(\mathrm{H}_{2} \mathrm{~L}\right)$ & $\mathrm{pH}-$ pot & $3.66 \pm 0.01^{\mathrm{c}}$ & - & $3.89 \pm 0.02$ & $4.99^{\mathrm{d}}$ \\
$\mathrm{p} K_{\mathrm{a}}(\mathrm{HL})$ & $\mathrm{pH}-\mathrm{pot}$ & $9.72 \pm 0.01^{\mathrm{c}}$ & $8.47 \pm 0.01$ & $8.46 \pm 0.02$ & $9.51^{\mathrm{d}}$ \\
$\mathrm{p} K_{\mathrm{a}}\left(\mathrm{H}_{2} \mathrm{~L}\right)$ & $\mathrm{UV}-$-vis & $3.57 \pm 0.02$ & - & $3.70 \pm 0.04^{\mathrm{f}}$ & $4.90 \pm 0.02^{\mathrm{g}}$ \\
$\mathrm{p} K_{\mathrm{a}}(\mathrm{HL})$ & $\mathrm{UV}-$-vis & $9.70 \pm 0.02$ & $8.39 \pm 0.02^{\mathrm{e}}$ & $8.27 \pm 0.04^{\mathrm{f}}$ & $9.63 \pm 0.02^{\mathrm{g}}$ \\
$\log \beta[\mathrm{InL}]$ & $\mathrm{pH}-$ pot & $13.67 \pm 0.04^{\mathrm{h}}$ & $11.03 \pm 0.03$ & $12.64 \pm 0.05$ & - \\
$\log \beta\left[\mathrm{InL}_{2}\right]$ & $\mathrm{pH}-$ pot & $23.50 \pm 0.06^{\mathrm{h}}$ & $18.59 \pm 0.03$ & $21.31 \pm 0.07$ & - \\
$\log \beta\left[\mathrm{InL}_{3}\right]$ & $\mathrm{pH}-$ pot & $32.66 \pm 0.08^{\mathrm{h}}$ & $24.38 \pm 0.05$ & $28.95 \pm 0.09$ & - \\
$\log \beta\left[\mathrm{InL}^{\mathrm{h}}\right]$ & $\mathrm{UV}-\mathrm{vis}$ & $13.72 \pm 0.03$ & $10.77 \pm 0.03$ & $12.29 \pm 0.06$ & $13.43 \pm 0.06$ \\
$\log \beta\left[\mathrm{InL}_{2}\right]$ & $\mathrm{UV}-\mathrm{vis}$ & $23.88 \pm 0.06$ & $18.78 \pm 0.03$ & $21.18 \pm 0.06$ & $22.87 \pm 0.03$ \\
$\log \beta\left[\mathrm{InL}_{3}\right]$ & $\mathrm{UV}-\mathrm{vis}$ & $33.45 \pm 0.03$ & $25.04 \pm 0.06$ & $29.66 \pm 0.06$ & $32.64 \pm 0.06$ \\
$\mathrm{pIn} *$ & & 7.95 & 6.01 & 7.93 & 8.18 \\
$\mathrm{pGa} *$ & & $8.83^{\mathrm{i}}$ & $6.00^{\mathrm{j}}$ & $7.92^{\mathrm{j}}$ & $7.86^{\mathrm{j}}$ \\
\hline
\end{tabular}

${ }^{a}$ Hydrolysis constants for $\mathrm{In}(\mathrm{III}): \log \beta\left[\mathrm{InH}_{-1}\right]=-4.30, \log \beta\left[\mathrm{InH}_{-2}\right]=-9.40, \log \beta\left[\mathrm{InH}_{-3}\right]=-13.90$, $\log \beta\left[\mathrm{InH}_{-4}\right]=-23.40$ [27]. Stability constants for $\mathrm{In}(\mathrm{III})$ chloride complexes: $\log \beta[\mathrm{InCl}]=2.32$, $\log \beta\left[\mathrm{InCl}_{2}\right]=3.62, \log \beta\left[\mathrm{InCl}_{3}\right]=4.00$ [28]. ${ }^{\mathrm{b}} \mathrm{Chlorido}$ complex formation is negligible at these conditions. ${ }^{\mathrm{c}} \mathrm{p} K_{\mathrm{a}}\left(\mathrm{H}_{2} \mathrm{~L}\right)=3.67, \mathrm{p} K_{\mathrm{a}}(\mathrm{HL})=9.77, I=0.2 \mathrm{M}(\mathrm{KCl})$ Ref. [31]. ${ }^{\mathrm{d}}$ Taken from Ref. [29]. ${ }^{\mathrm{e}} \mathrm{p} K_{\mathrm{a}}$ $(\mathrm{HL})=8.46, I=0.2 \mathrm{M}(\mathrm{KCl}) \operatorname{Ref}[29] .{ }^{\mathrm{f}} \mathrm{p} K_{\mathrm{a}}\left(\mathrm{H}_{2} \mathrm{~L}\right)=3.63, \mathrm{p} K_{\mathrm{a}}(\mathrm{HL})=8.48, I=0.2 \mathrm{M}\left(\mathrm{KNO}_{3}\right)$ Ref. [30]. ${ }_{\mathrm{g}} K_{\mathrm{a}}\left(\mathrm{H}_{2} \mathrm{~L}\right)=4.95, \mathrm{p} K_{\mathrm{a}}(\mathrm{HL})=9.75, I=0.2 \mathrm{M}(\mathrm{KCl}) \operatorname{Ref} .[29] .{ }^{\mathrm{h}} \log \beta[\mathrm{InL}]=13.60, \log \beta\left[\mathrm{InL}_{2}\right]=23.93$, $\log \beta\left[\mathrm{InL}_{3}\right]=32.93$ at $I=0.15 \mathrm{M} \mathrm{NaCl}$ [27]. ${ }^{\mathrm{i}}$ Computed based on stability constants taken from Ref. [27]. ${ }^{\mathrm{j}}$ Computed on the basis of stability constants taken from Ref. [29], hydrolysis constants for $\mathrm{Ga}(\mathrm{III}): \log \beta$ $\left[\mathrm{GaH}_{-1}\right]=-2.46, \log \beta\left[\mathrm{GaH}_{-2}\right]=-5.92, \log \beta\left[\mathrm{GaH}_{-3}\right]=-10.63, \log \beta\left[\mathrm{GaH}_{-4}\right]=-16.87$ [32] 

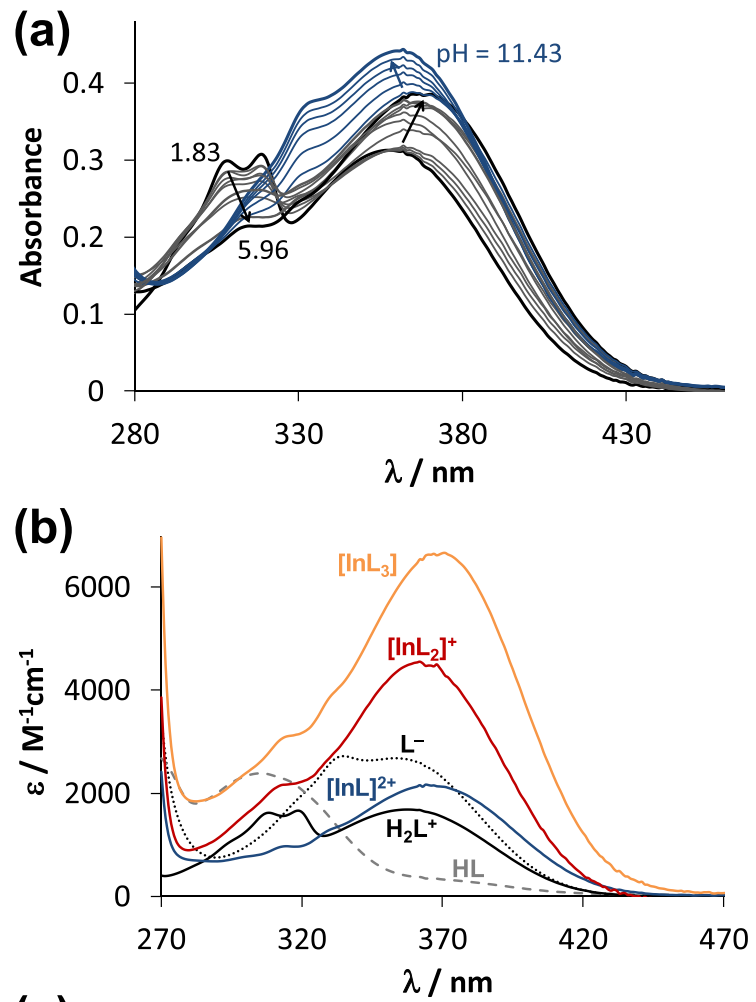

(c)

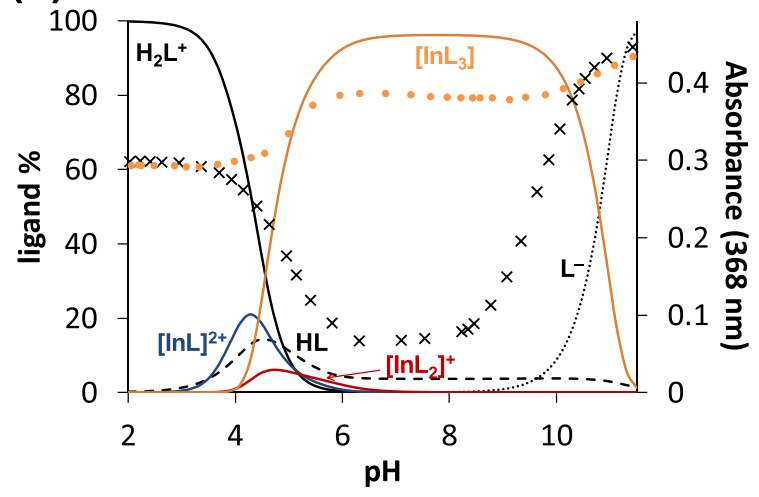

Fig. 1 a UV-vis spectra recorded for the In(III) - HQ (1:3) system at various $\mathrm{pH}$ values. b Computed molar spectra of the individual species. c Concentration distribution curves for the same system plotted together with the absorbance values at $368 \mathrm{~nm}(\mathbf{)})$ in addition to that of the metal-free ligand $(\times) .\left\{c_{\text {In(III) }}=28.3 \mu \mathrm{M}, c_{\mathrm{L}}=93.3 \mu \mathrm{M}\right.$, $\left.T=25.0{ }^{\circ} \mathrm{C}, I=0.20 \mathrm{M}(\mathrm{KCl}), \ell=2 \mathrm{~cm}\right\}$

although, the shape of the spectra is different and is quite similar to that was found for the Ga(III) complexes [29].

Based on the determined overall stability constants, concentration distribution curves were computed for the In(III) - HQ system (Fig. 1c) representing the predominant formation of $\left[\mathrm{InL}_{3}\right]$ complex (where $\mathrm{L}$ is the completely deprotonated form of the ligand) between $\mathrm{pH} 6$ and 9.5. The same phenomenon was found for the analogous $\mathrm{Ga}(\mathrm{III}) \mathrm{com}$ plexes [29]. Both metal ions form the tris-ligand complex at physiological $\mathrm{pH}$, however, different isomers are present

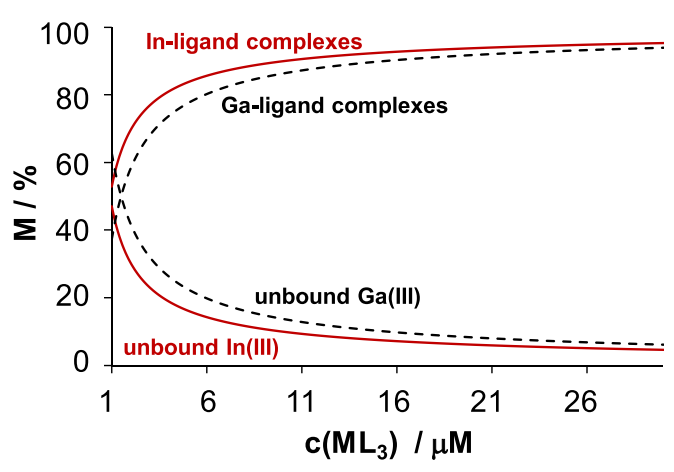

Fig. 2 Estimated distribution of the tris-ligand HQ complexes of In(III) (solid lines) and $\mathrm{Ga}(\mathrm{III})$ (dashed lines) at $\mathrm{pH} 7.4$ at various total concentrations. The majority $(\geq 98 \%)$ of the ligand-bound complexes is present as $\mathrm{InQ}_{3}$ and $\mathrm{GaQ}_{3}$, and practically $100 \%$ of the unbound metal ions is found in hydroxido complexes. $\left\{T=25.0^{\circ} \mathrm{C}\right.$, $I=0.20 \mathrm{M}(\mathrm{KCl})\}$

in solution, mer-isomers are predominant for $\mathrm{Ga}(\mathrm{III})$ while fac-complexes form with In(III) [35, 36]. The equilibrium concentration of the two tris-ligand complexes strongly depends on their total concentration as represented in Fig. 2. The fraction of the tris-ligand complex decreases somewhat more significantly with decreasing total concentration in the case of $\mathrm{Ga}(\mathrm{III})$. Despite the higher overall stability constants of $\mathrm{Ga}$ (III) complexes over the In(III) species, the stronger tendency of $\mathrm{Ga}$ (III) ions to hydrolysis results in a somewhat lower conditional stability at $\mathrm{pH} 7.4$.

To compare the In(III) binding ability of the studied four ligands, pIn* (= negative decadic logarithm of the equilibrium concentration of the unbound metal species) values were calculated at $\mathrm{pH} 7.4$ using the determined stability constants (Table 1). These values take into account the hydrolysis of the metal ions (Table 1, see Table S1 for pIn values) and can be compared to each other, which reveal the following stability trend for In(III): HQ $>$ deferiprone, HQS $>>$ maltol. Similarly, $\mathrm{pGa}^{*}$ values were also calculated (Table 1) representing a somewhat different stability order: deferiprone $>\mathrm{HQS}, \mathrm{HQ}>>$ maltol. The affinity of the studied ligands towards In(III) and Ga(III) do not differ considerably.

\section{Interaction of tris-ligand complexes with low molecular mass serum components}

As a first step, interaction of the tris-ligand In(III) complexes with various LMM blood serum components was investigated and compared to that of $\mathrm{GaQ}_{3}$ studied formerly in our research group [22, 29]. The LMM compounds are considered to be more mobile than the high molecular mass components (HMM) such as proteins, and generally their reaction is characterized by faster kinetics. The role of serum 
compounds might have importance on the distribution of the In(III) complexes since they may be responsible for (partial) displacement of the originally coordinated ligand and they can also form mixed-ligand complexes. The complexes of $\mathrm{In}(\mathrm{III})$ and $\mathrm{Ga}(\mathrm{III})$ formed with $\mathrm{HQ}\left(\mathrm{InQ}_{3}, \mathrm{GaQ}_{3}\right)$, deferiprone $\left(\mathrm{InD}_{3}\right)$ and maltol $\left(\mathrm{InM}_{3}\right)$ were prepared in an aqueous solution by mixing the respective ligand and the metal ion in 3:1 ratio. The interaction of the In(III) complexes with serum components was followed at $\mathrm{pH} 7.40$ in $10 \mathrm{mM}$ HEPES containing $100 \mathrm{mM} \mathrm{NaCl}$ and $25 \mathrm{mM} \mathrm{NaHCO}_{3}$. All the measurements in this work were performed at $25^{\circ} \mathrm{C}$ as most of the stability constants used for the modeling calculations published in the literature were determined at this temperature. UV-vis spectra recorded for the tris-ligand complexes at $10 \mu \mathrm{M}$ concentration (see Fig. S1a for $\operatorname{InQ}_{3}$ ) in this buffer show $94 \%, 90 \%$ and $<20 \%$ non-dissociated $\operatorname{InQ}_{3}$, $\mathrm{InD}_{3}$ and $\mathrm{InM}_{3}$, respectively, which corresponds well to the fractions obtained using the stability constants determined at $0.20 \mathrm{M} \mathrm{KCl}: 90 \%\left(\mathrm{InQ}_{3}\right), 86 \%\left(\mathrm{InD}_{3}\right)$ and $9 \% \mathrm{InM}_{3}$ and $6 \%$ $\mathrm{InM}^{2+}$. While $\mathrm{InQ}_{3}$ is somewhat more stable in comparison to $\mathrm{GaQ}_{3}(86 \%)$ [29]. $\mathrm{InM}_{3}$ is not stable enough at physiologically relevant low micromolar concentrations; therefore, no detailed investigations were conducted with this complex.

In(III) ion, as a hard Lewis acid, favors oxygen-donor chelating ligands, therefore, the effect of phosphate $(1.1 \mathrm{mM})$, citrate $(98 \mathrm{uM})$, and oxalate $(9.3 \mathrm{uM})$, on the stability of $\mathrm{InQ}_{3}$ was investigated which are present in the blood plasma in considerable concentrations [37]. It was found that the UV-vis spectra of $\mathrm{InQ}_{3}$ were moderately affected by the addition of the mixture containing citrate, phosphate and oxalate in physiological concentration, and $c a .80 \%$ of the tris-ligand complex is present in its original form (Fig. S1), while the addition of tenfold excess of these LMM ligands resulted in significant dissociation of the complex (ca. 34\% complex remained). In comparison, the Ga(III) complexes $\mathrm{GaQ}_{3}$ and $\mathrm{GaM}_{3}$ were practically not affected by the addition of the same LMM competitors in tenfold excess; although, the effect of the LMM components was investigated separately and not via the use of their mixture [22].

\section{Interaction of $\operatorname{In} Q_{3}$ and $\operatorname{In} D_{3}$ with human serum albumin}

HSA is a universal transporter and the most abundant plasma protein with a concentration of $c a .630 \mu \mathrm{M}$ in human blood plasma. It possesses three hydrophobic binding sites located in subdomains IIA, IIIA and IB, which are referred as the site I, II and III, respectively [38, 39]. There are metalbinding sites on HSA as well, e.g. multi-metal binding site, cysteine-34, and $\mathrm{N}$-terminal site, however, these can provide coordination sites for metal ions of soft and borderline Lewis acid character (e.g. $\mathrm{Hg}(\mathrm{II}), \mathrm{Pt}(\mathrm{II}), \mathrm{Cu}(\mathrm{II}), \mathrm{Zn}(\mathrm{II}))$ [40, 41]. The binding of hard metal ions such as $\mathrm{Al}(\mathrm{III}), \mathrm{Ga}$ (III) and
In(III) ions towards HSA are scarcely reported [20, 40]. This way, binding of the intact metal complexes on HSA via noncovalent bonds is more likely.

The effect of HSA on the intrinsic fluorescence of $\operatorname{InQ}_{3}$ and $\mathrm{InD}_{3}$ was studied. Similarly to $\mathrm{GaQ}_{3}$ and tris(8-hydroxyquinolinato) $\mathrm{Al}(\mathrm{III})$ [22, 42], $\mathrm{InQ}_{3}$ and $\mathrm{InD}_{3}$ are also fluorescent metal complexes (see Table 2 for $\lambda_{\max }$ values). We have found that the fluorescence of $\mathrm{InQ}_{3}$ does not overlap with that of HSA, which makes the interpretation of the measured emission spectra (Fig. 3) easier. The fluorescence intensity of $\mathrm{InQ}_{3}$ increased in the presence of HSA, and emission intensity values measured at $530 \mathrm{~nm}$ show a saturation character plotted against the added HSA equivalents. The interaction was found to be rapid as it took place within a few seconds. At the same time, UV-vis absorbance spectra of $\mathrm{InQ}_{3}$ are only slightly altered by the binding interaction. Enhanced fluorescence of $\mathrm{InQ}_{3}$, and fast binding kinetics confirm the binding of the non-dissociated metal complex to the protein via intermolecular interactions. Fluorometric data can be excellently fitted with the computer program PSEQUAD [43] assuming a single site model (see Fig. 3), and a conditional binding constant of $\log K^{\prime}=5.0 \pm 0.1$ was calculated for the HSA $-\mathrm{InQ}_{3}$ adduct. This constant indicates a moderate affinity of the complex on $\mathrm{HSA} . \mathrm{GaQ}_{3}$ itself binds to HSA, but a considerably lower binding constant was determined for this complex $\left(\log K^{\prime}=4.04\right)$, while $\mathrm{GaM}_{3}$ showed no interaction with this protein [22]. The fluorescence spectra of $\mathrm{InD}_{3}$ and HSA overlap significantly (see Fig. S2); although the intensities are additive, therefore, no considerable binding of $\mathrm{InD}_{3}$ on HSA is suggested. Ultrafiltration experiments revealed that only ca. $8 \% \mathrm{InD}_{3}$ complex was bound to 2.5 equiv. protein and interestingly small

Table 2 Excitation $\left(\lambda_{\mathrm{EX}}\right)$ and emission maxima $\left(\lambda_{\mathrm{EM}}\right)$ of $\mathrm{InQ}_{3}$ and $\mathrm{GaQ}_{3}$ complexes and fluorescence lifetime $\left(\tau_{\mathrm{i}}\right)$ and amplitude $\left(\alpha_{\mathrm{i}}\right)$ values alone and in the presence of HSA in various concentrations at $\mathrm{pH}=7.40 .\left\{c_{\text {complex }}=10 \mu \mathrm{M} ; c_{\mathrm{HSA}}=2-10 \mu \mathrm{M} ; T=25.0^{\circ} \mathrm{C}\right.$; in $10 \mathrm{mM}$ HEPES, $25 \mathrm{mM} \mathrm{NaHCO}_{3}, 100 \mathrm{mM} \mathrm{NaCl}$ buffer $\}^{\mathrm{a}}$

\begin{tabular}{lll}
\hline & $\mathrm{InQ}_{3}{ }^{\mathrm{b}}$ & $\mathrm{GaQ}_{3}$ \\
\hline$\lambda_{\text {EX max }}(\mathrm{nm})$ & 254,370 & $367^{\mathrm{c}}$ \\
$\lambda_{\mathrm{EM} \text { max }}(\mathrm{nm})$ & 540 & $532^{\mathrm{c}}$ \\
\multicolumn{2}{c}{ Fluorescence lifetime parameters of the complexes alone } \\
$\tau_{1}(\mathrm{~ns})$ & $0.80 \pm 0.03$ & $0.54 \pm 0.04$ \\
$\tau_{2}(\mathrm{~ns})$ & $1.41 \pm 0.07$ & $1.23 \pm 0.03$ \\
$\alpha_{1}(\%)$ & $75 \pm 4$ & $57 \pm 5$ \\
$\alpha_{2}(\%)$ & $25 \pm 4$ & $43 \pm 5$ \\
Two additional lifetime components in the presence of HSA \\
$\tau_{3}(\mathrm{~ns})$ & $5.7 \pm 0.3$ & $5.0 \pm 0.3$ \\
$\tau_{4}(\mathrm{~ns})$ & $13.8 \pm 0.6$ & $14.0 \pm 0.2$ \\
\hline
\end{tabular}

${ }^{a}$ Values are the average of at least three measurements. ${ }^{b}$ Data for $\mathrm{InD}_{3}: \lambda_{\mathrm{EX} \max }=295 \mathrm{~nm}, \lambda_{\mathrm{EX} \max }=354 \mathrm{~nm}$. ${ }^{\mathrm{c} D a t a}$ taken form Refs. [22, 29] 
Fig. 3 a Fluorescence spectra of $\mathrm{InQ}_{3}$ alone (thick black line) and in the presence of increasing amounts of HSA (grey lines). b Experimental $(\mathbf{O})$ and fitted (solid line) intensities of the same system at $\lambda_{\mathrm{EM}}=530 \mathrm{~nm}$. $\left\{c_{\text {complex }}=18 \mu \mathrm{M} ; c_{\mathrm{HSA}}=0\right.$ $-124 \mu \mathrm{M} ; \lambda_{\mathrm{EX}}=367 \mathrm{~nm}$; $\mathrm{pH}=7.40\}$
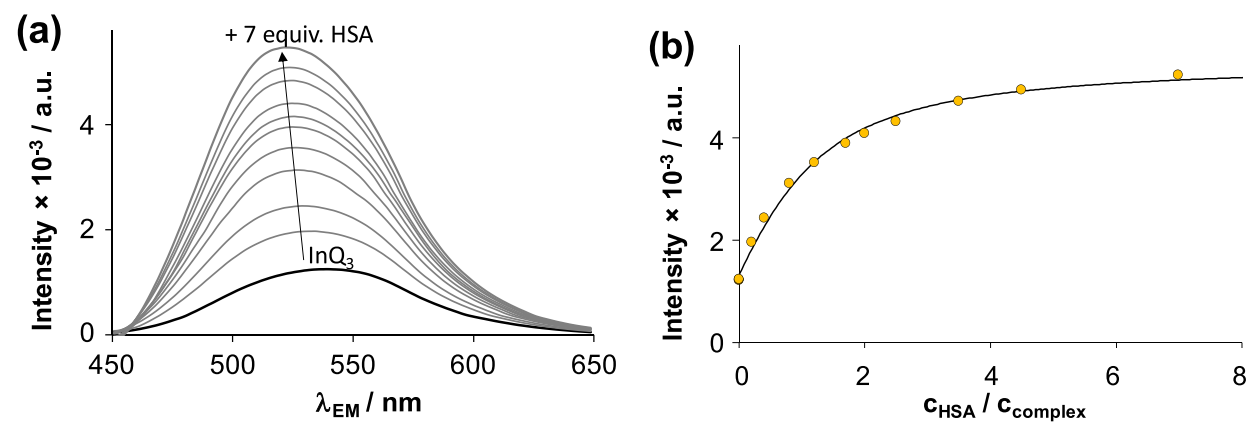

deferiprone liberation refers to the binding of $c a .7 \% \operatorname{In}(\mathrm{III})$ ion to the protein in addition [20].

Binding at the site I hydrophobic pocket of HSA can be followed via the selective excitation $\left(\lambda_{\mathrm{EX}}=295 \mathrm{~nm}\right)$ of the single Trp (Trp-214) located close to this site. Trp-214 is sensitive to the binding events taking place at or near this site. The $\mathrm{InQ}_{3}$ complex quenched effectively the fluorescence of HSA, and a quenching constant $\left(K^{\prime}{ }_{\mathrm{Q}}\right)$ could be computed based on the measured spectra: $\log K^{\prime}{ }_{\mathrm{Q}}=5.1 \pm 0.1$. This quenching constant is rather similar to the constant obtained from spectral data collected at $\lambda_{\mathrm{EX}}=370 \mathrm{~nm}$ (vide supra), which strongly suggests the existence of a single binding site of $\mathrm{InQ}_{3}$ on HSA at the site I. The quenching of Trp-214 fluorescence most probably originates from (fluorescence) resonance energy transfer (FRET, or RET) mechanism, more details on this phenomenon can be found in Fig. S3 [44].

The fluorescence lifetime of $\mathrm{InQ}_{3}$ was determined in the absence and presence of $\mathrm{HSA}$. $\mathrm{InQ}_{3}$ possesses a bi-exponential fluorescence decay characterized by $\tau_{1}=0.79 \pm 0.03 \mathrm{~ns}$ and $\tau_{2}=1.39 \pm 0.05 \mathrm{~ns}$; and the amplitudes $\left(\alpha_{i}\right)$ of the two components practically did not depend on the applied concentration of the complex in the 5-20 $\mu \mathrm{M}$ range. $\mathrm{GaQ}_{3}$ behaves similarly (Table 2), while lifetimes of $\mathrm{InD}_{3}$ were too short ( $\tau \leq 0.2 \mathrm{~ns}$ ) for accurate determination with our instrument. By the addition of HSA to the complex, two additional lifetime components appeared for $\mathrm{InQ}_{3}: \tau_{3}=5.7 \pm 0.3 \mathrm{~ns}$ and $\tau_{4}=13.8 \pm 0.6 \mathrm{~ns}$, which correspond to the HSA bound forms. The two 'bound' lifetimes do not consequently mean the presence of two distinct binding sites, but possibly reflects the bi-exponential decay of the complex [45]. The $\mathrm{GaQ}_{3}$ - HSA system could be characterized with similar lifetime parameters (Table 2).

\section{Interaction of $\ln Q_{3}$ and $\operatorname{lnD} 3$ with human transferrin}

Transferrin is the major iron transporter in blood and consists of two domains each possessing an iron-binding site called $\mathrm{C}$ - and $\mathrm{N}$-terminal sites. Tf is not completely saturated with $\mathrm{Fe}$ (III) under physiological conditions; and approximately $70 \%$ of the binding sites are available for various metal ions. The binding of several metal ions to apo-transferrin (apoTf, iron-free $\mathrm{Tf}$ ) has been investigated and trivalent metal ions, e.g. $\mathrm{Al}(\mathrm{III}), \mathrm{Ga}(\mathrm{III}), \mathrm{In}(\mathrm{III})$ or lanthanide ions, can bind with high affinity at the iron-binding sites [19, 23, 37, 46, 47]. Interaction of metal complexes with (apo)Tf, if it takes place, is most likely competition between the original ligand(s) and (apo)Tf for the metal ion.

Firstly, the kinetics of the reaction between apoTf and $\mathrm{InCl}_{3}$ and the complexes was studied by UV-vis spectrophotometry. The reaction of 2 equiv. $\mathrm{InCl}_{3}$ with apoTf took $c a$. $2 \mathrm{~h}$, and the presence of excess citrate (10 equiv. to $\mathrm{InCl}_{3}$ ) did not considerably increase the reaction rate (Fig. S4). These observations and spectral changes displayed by apoTf in the presence of In(III) ions (Fig. S4) agree well with the findings of Battistuzzi et al. [25]. At the same time Harris et al. have observed slow equilibration with $\mathrm{InCl}_{3}$, that was accelerated (to $6 \mathrm{~h}$ ) in the presence of NTA [18]. In the case of $\mathrm{InQ}_{3}$ and $\mathrm{InD}_{3}$, the progress of apoTf binding could be followed through the ligand bands of the complexes. The equilibrium was reached in $c a .3-4 \mathrm{~h}$ and $0.5 \mathrm{~h}$ for $\mathrm{InQ}_{3}$ and $\mathrm{InD}_{3}$, respectively. The $\mathrm{Ga}(\mathrm{III})$-analogue $\mathrm{GaQ}_{3}$ interacted within $1 \mathrm{~h}$ with apoTf under similar conditions [22].

Fluorescence quenching is a convenient technique to study the binding of metal ions at the iron-binding sites of apoTf since it results in reduced fluorescence intensity of Tf. Batch samples containing $1 \mu \mathrm{M}$ apoTf and various amounts of In(III) compounds were prepared. As Fig. 4a shows, the addition of $\mathrm{InD}_{3}$ quenched the fluorescence intensity of apoTf, the emission maximum was slightly red shifted and the emission stabilized at $c a .83 \%$ of the initial intensity. The quenching curve shown at $\lambda_{\mathrm{EM}}=330 \mathrm{~nm}$ (inset of Fig. 4a) possesses a definite breakpoint at complex-to-Tf ratio of $c a$. 2, which suggests the competitiveness of Tf with deferiprone for the binding of In(III). Rather similar behaviour was observed for $\mathrm{InCl}_{3}$ and $\mathrm{InM}_{3}$, which later is almost completely dissociated at this concentration (Fig. 4b). The partial (and not complete) quenching of apoTf can be explained by the presence of numerous Tyr (26) and Trp (8) residues in the protein among which only a few are affected by the binding of In(III) at the iron-binding sites [48]. Upon addition of $\mathrm{InQ}_{3}$, the quenching curve is more stretched and aims to lower intensities (Fig. 4b). Interaction of the non-dissociated 


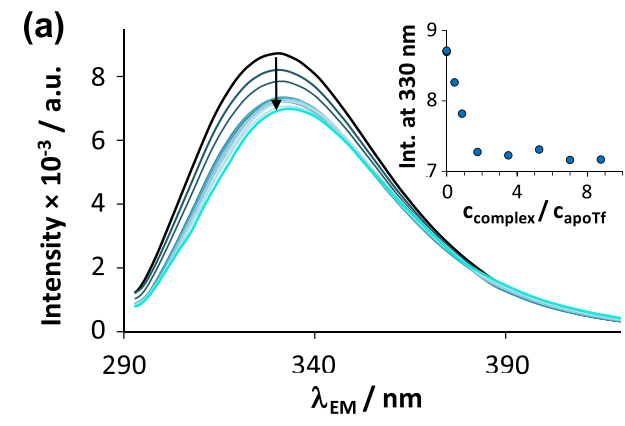

Fig. 4 a Fluorescence emission spectra of apoTf in the presence of various amounts of $\mathrm{InD}_{3}$, inset shows the intensity changes at $330 \mathrm{~nm}$. b Comparison of the fluorescence intensities of apoTf by addition of $\mathrm{InCl}_{3}(\boldsymbol{\square}), \mathrm{InM}_{3}(\bullet) \mathrm{InD}_{3}(\bullet)$ and $\mathrm{InQ}_{3}(\boldsymbol{\Delta})$ at $330 \mathrm{~nm}$

complex $\mathrm{InQ}_{3}$ with apoTf cannot be excluded, the latter proposed interaction is realized via intermolecular binding mode and more likely takes place on site(s) other than the iron-binding pockets (vide infra).

Complex $\mathrm{InQ}_{3}$ has a characteristic absorbance band at $370 \mathrm{~nm}$ and it is fluorescent as well, while ligand HQ absorbs light at shorter wavelengths $\left(\lambda_{\max }=305 \mathrm{~nm}\right)$ at $\mathrm{pH}$ 7.4 and displays negligible fluorescence. Therefore, UV-vis and fluorescence emission spectra of $\mathrm{InQ}_{3}$ were recorded in the presence of increasing amounts of apoTf (Fig. 5a, b). After a short initial phase, the absorbance band of $\operatorname{InQ}_{3}$ (b)

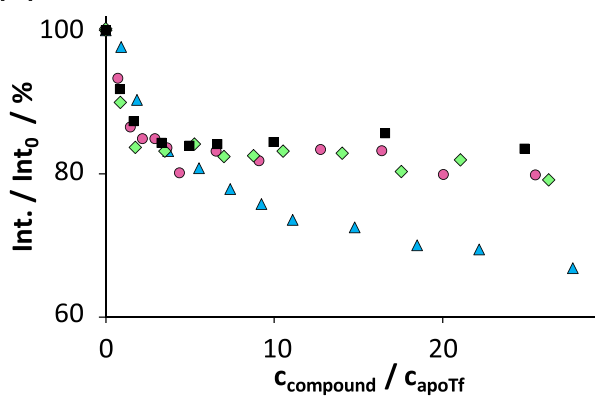

plotted against the ratio $c_{\text {compound }} / c_{\text {apoTf }} \cdot\left\{c_{\text {apoTf }}=1 \mu \mathrm{M}, c_{\text {compound }}=0\right.$ - ca. $30 \mu \mathrm{M} ; \lambda_{\mathrm{EX}}=280 \mathrm{~nm} ; \mathrm{pH} 7.40$ equilibration time: $1 \mathrm{~h}\left(\mathrm{InD}_{3}\right)$, $\left.3 \mathrm{~h}\left(\mathrm{InCl}_{3}, \mathrm{InM}_{3}\right), 6 \mathrm{~h}\left(\mathrm{InQ}_{3}\right)\right\}$

is reduced gradually by the addition of the protein, while the development of the new band at lower wavelengths (at ca. $310 \mathrm{~nm}$ ) refers to the liberation of HQ. Namely, there is a competition for In(III) ion between the ligand and the iron-binding sites of apoTf. Absorbance values depicted at $370 \mathrm{~nm}$ and $310 \mathrm{~nm}$ (Fig. 5c) saturate roughly to the corresponding values of the free ligand and outline a sigmoidal shape. Fluorescence intensity of the same sample set (Fig. 5b, d) was enhanced and moderately blue shifted (from $\lambda_{\max }=540 \mathrm{~nm}$ to $532 \mathrm{~nm}$ ) until the addition of $c a .0 .2$ equiv. apoTf. Similar tendency was observed for $\mathrm{InQ}_{3}$ when it was

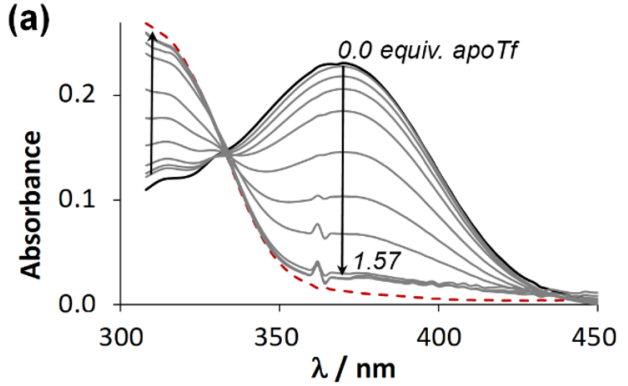

(b)

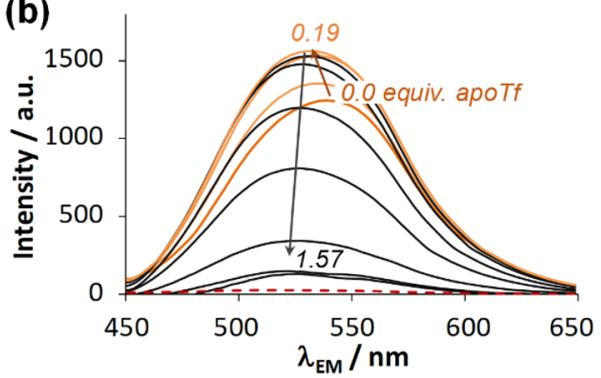

Fig. 5 a UV-vis absorbance and b fluorescence emission spectra recorded for $\mathrm{InQ}_{3}$ in the absence and presence of various amounts of apoTf, the spectrum of free HQ (red dashed line) is plotted as well. c Changes of the absorbance at $310 \mathrm{~nm}(\boldsymbol{O})$ and $370 \mathrm{~nm}(\boldsymbol{\Delta})$ (red dashed and blue dotted lines denote the absorbance belonging to free $\mathrm{HQ}$ at $310 \mathrm{~nm}$ and $370 \mathrm{~nm}$, respectively). d Fluorescence intensity at (c)

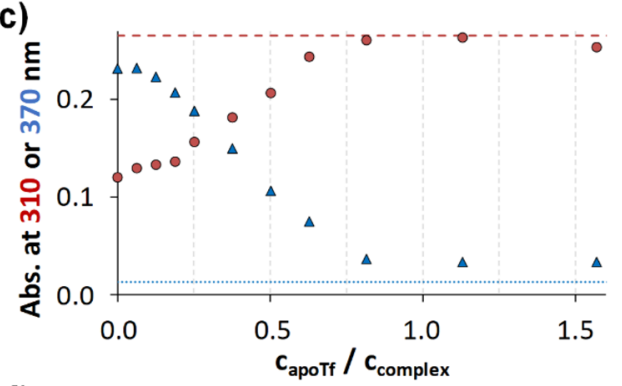

(d)

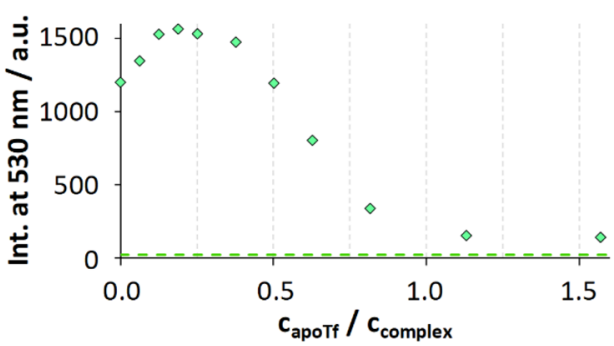

$\lambda_{\mathrm{EM}}=530 \mathrm{~nm}$ of the same system ( $\diamond$ ) (while the green dashed line shows the emission intensity of HQ). All the absorbance spectra are subtracted by the spectrum of apoTf. $\left\{c_{\text {complex }}=19 \mu \mathrm{M} ; c_{\text {apoTf }}=0-\right.$ $30 \mu \mathrm{M} ; c_{\mathrm{HQ}}=57 \mu \mathrm{M} ; \lambda_{\mathrm{EX}}=367 \mathrm{~nm}(\mathbf{c}) ; \ell=2 \mathrm{~cm}(\mathbf{a}, \mathbf{c}), 1 \times 1 \mathrm{~cm}(\mathbf{b}$, d); $\mathrm{pH}=7.40$, equilibration time: $6 \mathrm{~h}$ \} 
titrated by HSA (vide supra, Fig. 3). Then, by the addition of more apoTf, intensities decreased and $\lambda_{\max }$ shifted further to shorter wavelengths $(527 \mathrm{~nm})$. The interaction between apoTf and dissociated HQ can be excluded since no this kind of spectral changes could be observed for HQ - apoTf samples. Based on this and the results of apoTf quenching (vide supra) protein binding of the non-dissociated complex is presumed. This is further supported by fluorescence lifetime measurements; where new lifetime components $\tau_{3}=4.7 \pm 0.2 \mathrm{~ns}$ and $\tau_{4}=13.8 \pm 0.4 \mathrm{~ns}$ appeared for $\operatorname{InQ}_{3}$ in the presence of $0.1-0.3$ equiv. apoTf (after 1 min waiting time). These values are fairly similar to those observed for the $\mathrm{InQ}_{3}-\mathrm{HSA}$ system $\left(c f . \tau_{3}=5.7 \mathrm{~ns}, \tau_{4}=13.8 \mathrm{~ns}\right)$. In all, binding of the intact complex to apoTf is apparent at high complex excess preventing partly the coordination of In(III) at the iron-binding sites, then the latter process becomes more pronounced at higher apoTf concentrations. Samples were prepared also with $\mathrm{Tf}$ (loaded with iron in $c a$. 20-40\%). Here, the sigmoid shape of the UV-vis absorbance was seen again (Fig. S5) and the shifted inflection point in comparison to the titration with apoTf underlines the lower In(III) binding capacity of Tf. Interestingly, the fluorescence of these samples was practically unaltered till the addition of $c a .0 .3$ equiv. Tf. Binding of $\mathrm{GaQ}_{3}$ via intermolecular interactions to apoTf and $\mathrm{Tf}$ was also investigated for comparative reasons in this work, however, no such binding was observed.

In the case of $\mathrm{InD}_{3}$, the absorbance bands of the metal complex and apoTf overlap in great extent, however, spectra can be deconvoluted to the spectra of $\mathrm{InD}_{3}$, deferiprone and apoTf (see Fig S6 for details), and molar fractions of the respective species can be calculated (Fig. 6). Ultrafiltration experiments were carried out as well for the $\mathrm{InD}_{3}$ - apoTf system and the non-protein bound LMM fractions were analyzed by UV-vis spectrophotometry (Fig. 6). These ultrafiltration measurements corroborate the findings of the spectrophotometric assay. The complex dissociated in line

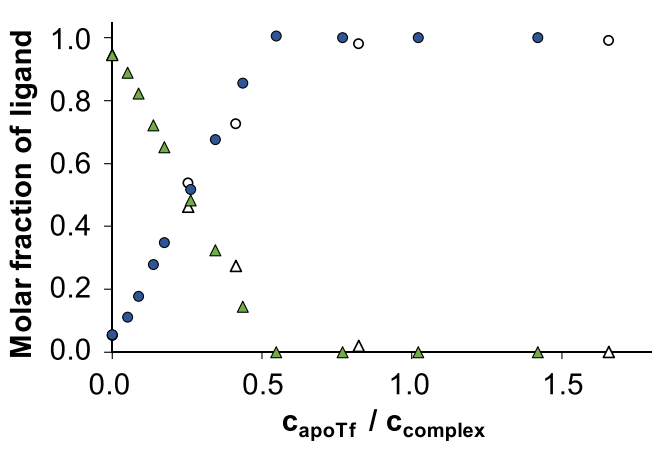

Fig. 6 Molar fractions of complex bound $\left(\mathrm{InD}_{3}, \boldsymbol{\Delta}, \Delta\right)$ and free deferiprone $(\mathbf{O}, \mathrm{O})$ calculated on the basis of UV-vis spectra recorded for the $\mathrm{InD}_{3}$ - apoTf system (filled symbols) and results of the ultrafiltration-UV-vis experiments (empty symbols) are plotted as well. $\left\{c_{\text {complex }}=22 \mu \mathrm{M}\right.$ (UV-vis), $19.8 \mu \mathrm{M}$ (ultrafiltration); $\left.\mathrm{pH}=7.40\right\}$ with the addition of apoTf and a practically quantitative displacement of deferiprone seems to take place by the addition of $c a$. 0.5 equiv. apoTf. Namely, both of the iron-binding sites participate in the binding of the In(III) ion.

Noteworthy, the competitiveness of apoTf for In(III) with the ligands deferiprone and HQ seems to be more significant as it would be assumed on the basis of stability constants reported for the $\mathrm{In}(\mathrm{III})$ - Tf system by Harris et al. ( $\log K$ $($ In-Tf $)=18.74$ and $\left.\log K\left(\operatorname{In}_{2}-\mathrm{Tf}\right)=16.86\right)$ [18]. Our results suggest about 2-3 orders of magnitude higher stability constants for the latter system under the conditions applied for the studies.

\section{Speciation of $\ln Q_{3}$ and $\mathrm{GaQ}_{3}$ in the presence of both serum proteins and in serum}

The reliability of UV-vis and fluorescence spectroscopic techniques in the characterization of the mode of interaction of In(III) complexes with HSA and (apo)Tf was proven in the former sections. Therefore, as a continuation threedimensional fluorescence and UV-vis spectra were recorded for $\mathrm{InQ}_{3}$ and $\mathrm{GaQ}_{3}$ in the presence of both HSA and Tf (Figs. 7 and S7).

In these experiments, the applied HSA-to-Tf ratio corresponds to their physiological ratio in blood serum (630:38). Figure 8 depicts the intensity changes of the ternary system (complex and both proteins) for $\mathrm{InQ}_{3}$ at $\lambda_{\mathrm{EX}}=367 \mathrm{~nm}$ and $\lambda_{\mathrm{EM}}=530 \mathrm{~nm}$ in comparison to the respective binary systems (complex and only one type of protein). Apparently, albumin binding of the complex is indeed achieved in the ternary system, although to a lower extent compared to the $\mathrm{InQ}_{3}$ - HSA binary system, and the Tf binding of In(III) becomes more significant at higher protein concentrations. Consequently, the measured intensity reduces parallel with the decreasing (free and albumin bound) $\mathrm{InQ}_{3}$ concentration. As Fig. 7 shows, $\mathrm{GaQ}_{3}$ and $\mathrm{InQ}_{3}$ complexes behave similarly at smaller protein concentrations added, and the moderate emission intensity of both complexes $(10 \mu \mathrm{M})$ is increased by the addition of a mixture of HSA (5.2 equiv.) and $\mathrm{Tf}$ ( 0.32 equiv.). Based on these spectra, $\mathrm{InQ}_{3}$ and $\mathrm{GaQ}_{3}$ are at least partly HSA-bound. However, minor dissociation of the complexes is evidenced by the UV-vis spectra (Fig. S7) even at this ratio that is more advanced for $\mathrm{InQ}_{3}$ than for $\mathrm{GaQ}_{3}$ (ca. $30 \%$ and $10 \%$ metal ion is $\mathrm{Tf}$ bound, respectively). The differences between the two complexes become more pronounced by getting closer to the physiologically relevant protein concentrations. In the presence of $212 \mu \mathrm{M}$ HSA and $12.8 \mu \mathrm{M}$ Tf (ratio: 1:21.2:1.28), the fluorescence of $\operatorname{InQ}_{3}$ is diminished, as most of the complex decomposes and In(III) is bound to $\mathrm{Tf}$. On the other hand, the $\mathrm{GaQ}_{3}$ containing sample is still highly fluorescent revealing significant albumin binding of the non-dissociated complex. UV-vis spectra confirmed the more moderate $(25 \%)$ dissociation of $\mathrm{GaQ}_{3}$ at 


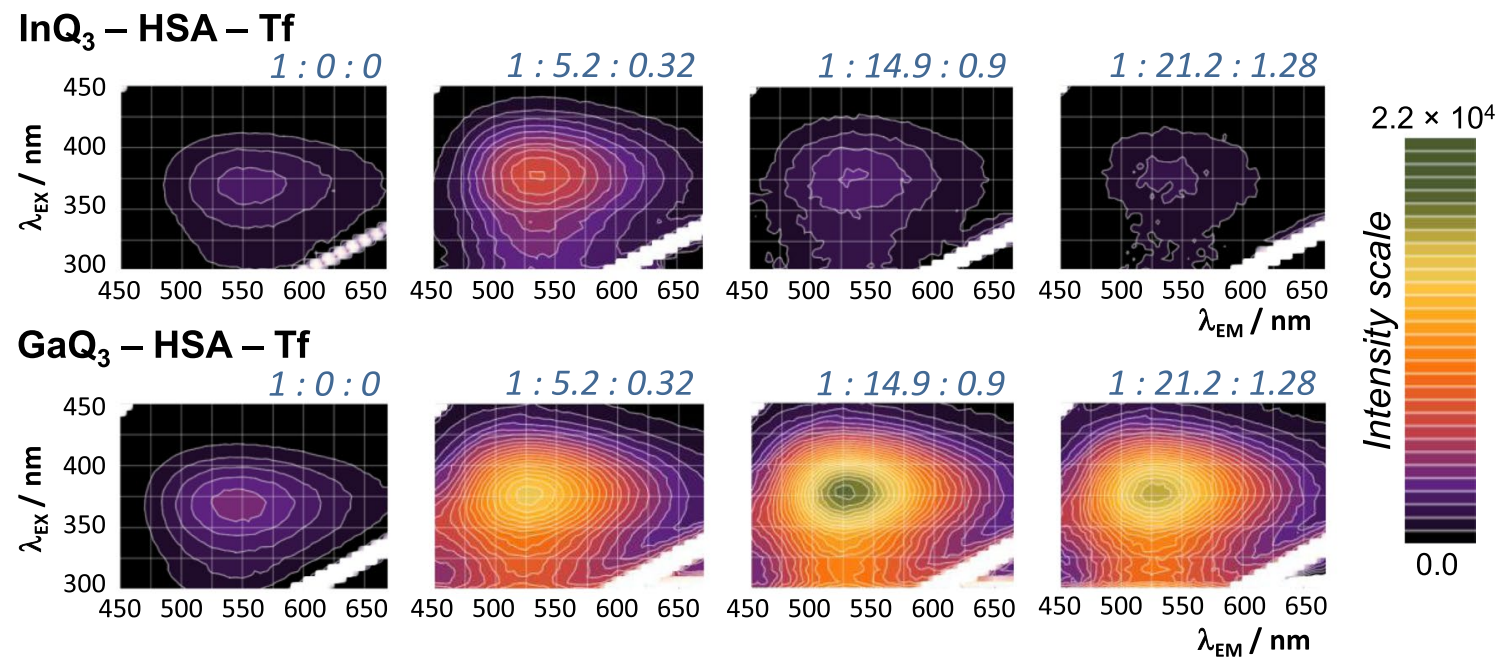

Fig.7 Three-dimensional fluorescence spectra recorded for $\mathrm{InQ}_{3}$ - HSA - Tf and $\mathrm{GaQ}_{3}$ - HSA - Tf ternary systems at the indicated compositions. Numbers indicate the complex-to-HSA-to-Tf ratios. The ratio of the two proteins corresponds to their physiological ratio

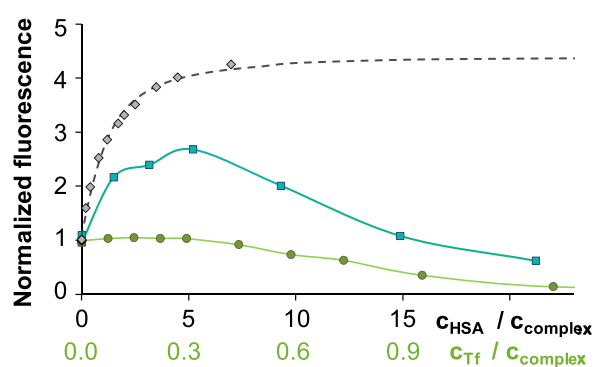

Fig. 8 Changes of fluorescence intensity in the $\operatorname{InQ}_{3}-\mathrm{HSA}-\mathrm{Tf}(\boldsymbol{\square})$, $\mathrm{InQ}_{3}-\mathrm{Tf}(\bullet)$ and $\mathrm{InQ}_{3}-\mathrm{HSA}(\diamond,---)$ ternary systems normalized for the emission intensity of the complex at $\lambda_{\mathrm{EM}}=550 \mathrm{~nm}$. Plotted values are derived from Fig. 7 (ternary system), Figure S5 (Tf) and Fig. 3 and the computed binding constant $\left(\log K^{\prime}=5.1\right)$ calculated for the $\mathrm{InQ}_{3}-\mathrm{HSA}$ system. $\left\{c_{\mathrm{InQ} 3}=10 \mu \mathrm{M} ; \mathrm{pH}=7.40 ; \lambda_{\mathrm{EX}}=367 \mathrm{~nm}\right.$; equilibration time: $6 \mathrm{~h}$; spectra are corrected by self-absorbance and inner filter effect

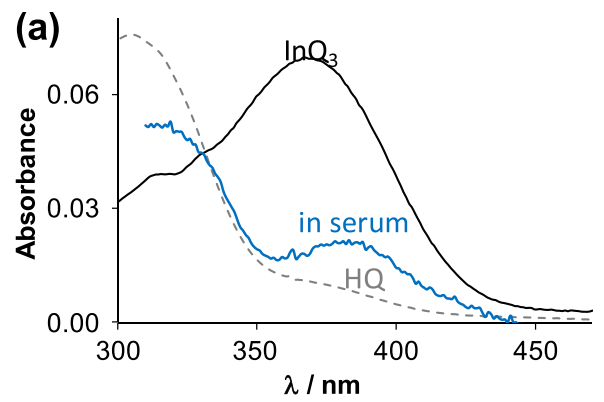

Fig. $9 \mathrm{UV}$-vis absorbance spectra recorded for $\mathrm{InQ}_{3}$ (a) and $\mathrm{GaQ}_{3}$ (b) in the absence (black lines) and presence of threefold diluted blood serum (blue lines) plotted together with the spectrum of free HQ (grey dotted line). Absorbance spectra of the mixtures are sub- in the blood serum. $\left\{c_{\mathrm{InQ} 3}=c_{\mathrm{GaQ} 3}=10 \mu \mathrm{M}, c_{\mathrm{HSA}}=0-212 \mu \mathrm{M} ; c_{\mathrm{Tf}}=0\right.$ - $12.8 \mu \mathrm{M} ; \mathrm{pH}=7.40$, equilibration time: $6 \mathrm{~h}$; spectra are corrected by self-absorbance and inner filter effect $\}$

this ratio compared to the practically completely dissociated $\mathrm{InQ}_{3}$ (Fig. S7). To mimic the blood protein concentrations, three-times higher values would be needed; however, under that conditions fluorometric detection becomes inadequate due to the too high absorbance and light scattering of the samples.

With this knowledge, samples prepared in blood serum were studied by UV-vis spectrometry to count the significance of HMM and LMM serum components in the speciation of the complexes (Figs. 9 and S8). Unfortunately, fluorescence spectra could not be recorded due to the significant light scattering of the samples. Interestingly, the chemical equilibrium was reached within 10 min between $10 \mu \mathrm{M}$ $\mathrm{GaQ}_{3}$ and threefold diluted serum based on the recorded $\mathrm{UV}$-vis spectra, while $4 \mathrm{~h}$ was needed when $\mathrm{InQ}_{3}$ was studied under the same conditions (Fig. S8). UV-vis spectra

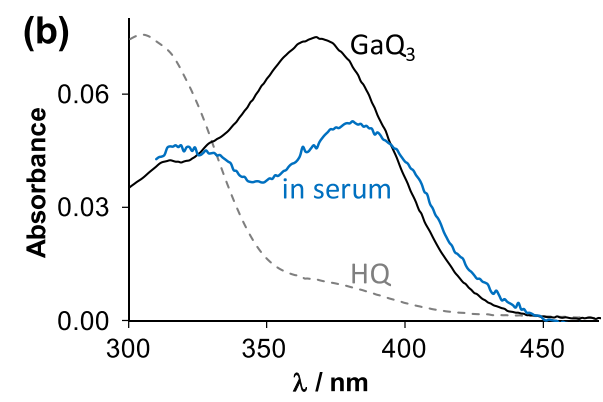

tracted by the spectrum of blood serum. $\left\{c_{\text {complexes }}=10 \mu \mathrm{M}\right.$; blood serum: filtered on $1.2 \mu \mathrm{m}$ filter and threefold diluted with buffer; $\ell=1 \mathrm{~cm} ; \mathrm{pH}=7.40$, equilibration time: $6 \mathrm{~h}$ \} 
in Fig. 9 resemble the behaviour observed for the complex - HSA - Tf ternary systems (Fig. S7) with some important differences. First, the $\lambda_{\max }$ of $\mathrm{GaQ}_{3}$ not only decreased slightly but also shifted to $382 \mathrm{~nm}$ in blood serum, while the absorption at $310 \mathrm{~nm}$ (that corresponds to the free ligand) did not increase in line with the decrease of the former band. This refers to the altered coordination sphere of the metal complex. With $\mathrm{InQ}_{3}$ the complex dissociation is more pronounced (see increasing absorption at $310 \mathrm{~nm}$ ); at the same time, the highly reduced complex band also shifts to $385 \mathrm{~nm}$. Keeping in mind the difficulties of interpretation of UV-vis spectroscopic data obtained in complex matrices, some assumptions can be made relying on the results of binary and ternary systems. Significant Tf binding of In(III) in blood serum is likely, while $\mathrm{GaQ}_{3}$ interacts less with this protein. The complex band was shifted only in serum samples; the presence of $\mathrm{HQ}$ - $\mathrm{Fe}$ (II)/(III) or $\mathrm{Cu}$ (II) complexes can be excluded on the basis of the obtained spectra [49, 50]. Formation of HQ - Mg(II) complex is not feasible even at physiological $\mathrm{Mg}$ (II) ion levels $(0.7-1.0 \mathrm{mM}$ ) based on the available stability constants [51]. $\mathrm{Zn}$ (II) ion forms higher stability complexes with $\mathrm{HQ}$ as $\mathrm{Mg}$ (II) $[51,52]$ and could compete for HQ with $\mathrm{In}(\mathrm{III})$ or $\mathrm{Ga}$ (III) if its total blood plasma concentration $(10-28 \mu \mathrm{M})$ would be freely available. Although $\mathrm{Zn}$ (II) ion forms complexes rapidly in general [53], the vast majority of this metal ion is bound to HMM ( $\alpha-1$ antitrypsin, HSA) and LMM serum components (histidine) in blood [54], therefore, the formation of $\mathrm{Zn}$ (II) - HQ complexes is not likely. The presence of mixed-ligand $\mathrm{In}(\mathrm{III}) / \mathrm{Ga}(\mathrm{III})-\mathrm{HQ}$ complexes is assumed with e.g. amino acids or small peptides.

Noteworthy, In(III) - Tf binding constants are smaller than those of $\mathrm{Ga}(\mathrm{III})$, at the same time, the stronger hydrolysis of $\mathrm{Ga}(\mathrm{III})$ ions at $\mathrm{pH} 7.4$ in comparison to In(III) ions leads to a reversal in apparent stability trend under the conditions applied. Our results suggest somewhat higher In(III)-Tf binding constants under the present conditions in comparison to the values reported by Harris et al. [18]. This way it is no surprise that complex $\mathrm{InQ}_{3}$ seems to be more prone to dissociate upon interaction with $\mathrm{Tf}$ (even in blood serum) in comparison to $\mathrm{GaQ}_{3}$.

\section{Conclusions}

Solution speciation of In(III) complexes of four bidentate ligands (maltol, deferiprone, HQ and HQS) was studied in pure water in the presence of $0.20 \mathrm{M}$ chloride ions. On the basis of the determined stability constants, tris-ligand complexes predominate at $\mathrm{pH} 7.4$ in most cases and their stability follows the trend of HQ > deferiprone, HQS > > maltol. Despite the higher overall stability constants of the trisHQ complex formed with Ga(III) over In(III), the stronger hydrolysis tendency of $\mathrm{Ga}$ (III) ions results in a somewhat lower conditional stability at $\mathrm{pH}$ 7.4. Directly measured and calculated fractions of the tris-ligand complexes at $10 \mu \mathrm{M}$ concentration and at $\mathrm{pH} 7.4$ reveal very low stability for the tris-maltolato complex $(<20 \%)$, while non-dissociated $\mathrm{InQ}_{3}$ and $\mathrm{InD}_{3}$ are present in solution in $c a .90 \% . \mathrm{InQ}_{3}$ displays reasonable stability ( $80 \%$ tris-ligand complex) in the presence of low molecular mass chelate forming ligands of blood plasma such as citrate, oxalate and phosphate.

Binding of $\mathrm{InCl}_{3}$ and the tris-ligand complexes $\mathrm{InD}_{3}$, $\mathrm{InM}_{3}, \mathrm{InQ}_{3}$ and its $\mathrm{Ga}(\mathrm{III})$ analogue $\mathrm{GaQ}_{3}$ to human serum albumin and human transferrin was monitored by steady-state and time-resolved spectrofluorometry, UV-vis spectrophotometry and membrane ultrafiltration. Our results revealed the moderate binding of $\mathrm{InQ}_{3}$ to HSA $\left(\log K^{\prime}=5.0-5.1\right)$. This binding constant is one order of magnitude higher than that reported for the $\mathrm{GaQ}_{3}-\mathrm{HSA}$ interaction. The fluorescence lifetimes of $\mathrm{InQ}_{3}$ and $\mathrm{GaQ}_{3}$ were determined and bi-exponential decays for the free and albumin-bound forms were found, respectively. The more hydrophilic $\mathrm{InD}_{3}$ can bind in a much lower extent to HSA. ApoTf can displace HQ, deferiprone and maltol effectively from their In(III) complexes. Substitution of deferiprone and maltol occurs to a much higher extent compared to that of $\mathrm{HQ}$, while Tf binding of non-dissociated $\mathrm{InQ}_{3}$ was also observed at high complex-to-Tf ratios, which could not be detected for $\mathrm{GaQ}_{3}$. Studies conducted with the $\mathrm{InQ}_{3} / \mathrm{GaQ}_{3}$ - HSA - Tf ternary systems reveal the more pronounced Tf binding of In(III), while $\mathrm{Ga}$ (III) remains preferably in the $\mathrm{GaQ}_{3}$ complex and binds to HSA to a greater extent. In human blood serum, a very similar role of $\mathrm{Tf}$ is presumed, and the remaining complexes may interact partly with LMM serum constituents. This behavior explains why ${ }^{111} \mathrm{InQ}_{3}$ cannot be administered into the blood directly and a previous blood cell labelling procedure is necessary, while circulating $\mathrm{GaQ}_{3}$, at least partly, can reach the target cells.

\section{Experimental}

\section{Chemicals}

$\mathrm{InCl}_{3}$, deferiprone, $\mathrm{HQ}, \mathrm{HQS}$, maltol, citric acid, oxalic acid, 4-(2-hydroxyethyl)-1-piperazineethanesulfonic acid (HEPES), HSA (product Nr.: A8763, essentially globulin free), apoTf (iron-free form, T2036), Tf containing physiological amount of iron (product Nr.: T3309, loaded with $\mathrm{Fe}(\mathrm{III})$ in $20-40 \%$ ) and human serum (from male $\mathrm{AB}$ plasma, H4522) were purchased from Sigma-Aldrich. Inorganic chemicals such as $\mathrm{KOH}, \mathrm{KCl}, \mathrm{HCl}, \mathrm{NaCl}, \mathrm{NaH}_{2} \mathrm{PO}_{4}$, $\mathrm{NaHCO}_{3}$ were products of Molar Chemicals or Reanal. 


\section{Stock solutions and sample preparation}

For the preparation of stock solutions and samples, Milli-Q water was used. Exact concentration of ligand stock solutions was determined via $\mathrm{pH}$-potentiometric titrations (vide infra). $\mathrm{InCl}_{3}$ and $\mathrm{GaCl}_{3}$ stock solutions were prepared by the dissolution of the anhydrous salts in a known amount of $\mathrm{HCl}$, and the concentration was determined by complexometry via the EDTA complexes. Stock solutions of the tris-ligand $\mathrm{In}(\mathrm{III})$ and $\mathrm{Ga}(\mathrm{III})$ complexes were prepared by mixing the metal ion and the corresponding ligand in 1:3 ratio in water, $c_{\text {complex }}=30-200 \mu \mathrm{M}$. Protein stock solutions were prepared in $10 \mathrm{mM}$ HEPES buffer containing $100 \mathrm{mM}$ $\mathrm{NaCl}$ and $25 \mathrm{mM} \mathrm{NaHCO}_{3}(\mathrm{pH}=7.40)$ and their concentration was calculated on the basis of their UV-Vis absorbance: $\varepsilon_{280 \mathrm{~nm}}(\mathrm{HSA})=36,850 \mathrm{M}^{-1} \mathrm{~cm}^{-1}, \varepsilon_{278 \mathrm{~nm}}($ apoTf $)=92,300$ $\mathrm{M}^{-1} \mathrm{~cm}^{-1}[55,56]$. The concentration of Tf stock solutions was determined based on the average molar weight reported by the producer and calculated molar absorbance at $280 \mathrm{~nm}$ fall between the reported values of apoTf and holoTf [57]. Serum was filtered on $1.2 \mu \mathrm{m}$ polyethersulfone syringe filters (OlimPeak, Teknokroma) and diluted with the buffer. The same buffer was used for sample preparation in protein binding studies. Samples containing the complexes $\operatorname{InQ}_{3}$, $\mathrm{InD}_{3}$ or $\mathrm{InCl}_{3}$ and apoTf or Tf were incubated for $6 \mathrm{~h}, 1 \mathrm{~h}$ and $3 \mathrm{~h}$, respectively. All samples were incubated at room temperature.

\section{pH-potentiometry}

The $\mathrm{pH}$-potentiometric measurements for the determination of the proton dissociation constants of the ligands (HQS, maltol, deferiprone) and the overall stability constants of their In(III) complexes were carried out at $25.0 \pm 0.1^{\circ} \mathrm{C}$ in water at an ionic strength of $0.20 \mathrm{M}$ (KCl, Sigma-Aldrich). The titrations were performed with a carbonate-free $\mathrm{KOH}$ solution of known concentration $(0.20 \mathrm{M})$. An Orion 710A $\mathrm{pH}$-meter equipped with a Metrohm combined electrode (type 6.0234.100) and a Metrohm 665 Dosimat burette were used for the $\mathrm{pH}$-potentiometric measurements. The electrode system was calibrated to the $\mathrm{pH}=-\log \left[\mathrm{H}^{+}\right]$scale using the method suggested by Irving et al. [58]. The average water ionization constant, $\mathrm{pK}_{\mathrm{w}}$, is $13.76 \pm 0.01$, which corresponds well to literature data [59]. The reproducibility of the titration points included in the calculations was within 0.005 $\mathrm{pH}$ units. The $\mathrm{pH}$-potentiometric titrations were performed in the $\mathrm{pH}$ range 2.0-11.5. The initial volume of the samples was $10.0 \mathrm{~mL}$, and the ligand concentration was $3 \mathrm{mM}$ and metal ion-to-ligand ratios of $1: 1$ to $1: 4$ were used. The fitting of the titration curves was less than $0.01 \mathrm{~mL}$. (The fitting parameter is the average difference between the experimental and calculated titration curves expressed in the volume of the titrant.) Samples were deoxygenated by bubbling purified argon through them for $c a .10$ min prior to the measurements. The proton dissociation constants of the ligands, the stoichiometry and the overall stability constants of the complexes were determined with the computer program HYPERQUAD [60]. Overall stability constants of the complexes $\left(\beta\left(\mathrm{M}_{p} \mathrm{~L}_{q} \mathrm{H}_{r}\right)\right)$ is defined for the general equilibrium $p \mathrm{M}+q \mathrm{~L}+r \mathrm{H} \rightleftharpoons \mathrm{M}_{p} \mathrm{~L}_{q} \mathrm{H}_{r}$ as $\beta\left(\mathrm{M}_{p} \mathrm{~L}_{q} \mathrm{H}_{r}\right)=\left[\mathrm{M}_{p} \mathrm{~L}_{q} \mathrm{H}_{r}\right] /$ $[\mathrm{M}]^{p}[\mathrm{~L}]^{q}[\mathrm{H}]^{r}$ where $\mathrm{M}$ denotes the metal ion and $\mathrm{L}$ the completely deprotonated ligand. Hydrolysis constants for In(III) and stability constants for the In(III)-chlorido complexes (Table 1) are taken from references [27, 28]. The calculations were always made from the experimental titration data measured in the absence of any precipitate in the solution.

\section{UV - visible spectrophotometry}

An Agilent Cary 8454 diode array spectrophotometer was used to obtain UV-visible (UV-vis) spectra in the interval $190-1100 \mathrm{~nm}$. The path length $(l)$ was 1 or $2 \mathrm{~cm}$.

Proton dissociation of the ligands (HQ, HQS, maltol, deferiprone) and overall stability constants and the individual spectra of their complexes were calculated with the computer program PSEQUAD [43]. The spectrophotometric titrations were performed on samples of the ligands with or without In(III); the concentration of the ligands was $0.10 \mathrm{mM}$, and the metal-to-ligand ratios were 1:1, 1:2, 1:3 and $1: 4$ over the $\mathrm{pH}$ range used in $\mathrm{pH}$-potentiometric measurements at $25.0 \pm 0.1^{\circ} \mathrm{C}$ at an ionic strength of $0.20 \mathrm{M}$ $(\mathrm{KCl})$.

For (apo)Tf containing samples, complex concentrations were $20 \mu \mathrm{M}$ and $0-2.5$ equiv. protein was added. Reference spectra for the complexes, ligands and protein were recorded as well. Samples prepared with blood serum contained threefold diluted serum and $10 \mu \mathrm{M}$ metal complexes. UV-vis spectra presented in this paper for complexes $\mathrm{InD}_{3}$ or $\mathrm{InQ}_{3}$ are subtracted by the spectrum of reference protein (HSA (apo)Tf or serum) sample in all cases in favour of the better interpretation of the results.

\section{Spectrofluorometry}

Fluorescence studies were implemented by a Fluoromax (Horiba Jobin Yvon) fluorometer in $1 \mathrm{~cm}$ quartz cells. Samples contained $1 \mu \mathrm{M}$ HSA or (apo)Tf and various protein-to-metal complex (or $\mathrm{InCl}_{3}$ ) ratios (up to complex/ HSA $=1: 30$ ) were used. The excitation wavelength was $295 \mathrm{~nm}$ and $280 \mathrm{~nm}$ for HSA and Tf binding studies, respectively; emission intensity was registered between 300 and $450 \mathrm{~nm}$. Intrinsic fluorescence of complex $\mathrm{InQ}_{3}$ was also followed at $\lambda_{\mathrm{EX}}=367 \mathrm{~nm}$, and $\lambda_{\mathrm{EM}}=450-650 \mathrm{~nm}$. In this setup, the complex concentration was $c a$. 10 or $20 \mu \mathrm{M}$, and protein (HSA, (apo)Tf) concentration was varied between 0 and $130 \mu \mathrm{M}$, and residual fluorescence of the proteins were 
subtracted if it was necessary. Corrections for self-absorbance and inner filter effect were done as described in our former work using the formula suggested by Lakowicz [22, 44]. Computer program PSEQUAD [43] was utilized for the calculation of binding constants $\left(K^{\prime}\right)$ for $\mathrm{HSA}-\mathrm{InQ}_{3}$ adducts similar to the approach described in our former works [22, 61]. Calculations were always based on data obtained from at least two independent measurements.

Three-dimensional spectra were recorded for ternary systems containing $\mathrm{InQ}_{3}$ or $\mathrm{GaQ}_{3}$, HSA and Tf in the wavelength range $\lambda_{\mathrm{EX}}=250-450 \mathrm{~nm}$ and $\lambda_{\mathrm{EM}}=300$ $-700 \mathrm{~nm}$. All three-dimensional spectra were corrected by residual fluorescence of the proteins, inner filter effect and self-absorbance.

Fluorescence lifetime was measured on the same fluorometer equipped with a DeltaHub time-correlated single photon counting (TCSPC) controller applying NanoLED light sources N-300 $\left(\lambda_{\max }=300 \mathrm{~nm}\right)$ and $\mathrm{N}-350\left(\lambda_{\max }=355 \mathrm{~nm}\right)$ (Horiba Jobin Yvon). Further instrumental settings are listed in Table S2. The background (obtained with blank samples) was subtracted from the decay of the samples. The program DAS6 (version 6.6.; Horiba, Jobin Yvon) was used for the analysis of the experimental fluorescence decays. The fluorescence intensity decay over time is described by a sum of exponentials,

$I(t)=\sum_{i=1}^{n} \alpha_{i} \exp \left(\frac{-t}{\tau_{i}}\right)$

where $\alpha_{i}$ and $\tau_{i}$ are the normalized amplitude and lifetime of component $i$ respectively [44]. The quality of the fit was judged from a $\chi_{\mathrm{R}}^{2}$ value close to 1.0 and a random distribution of weighted residuals.

\section{Ultrafiltration}

Samples containing $\mathrm{InD}_{3}$ and apoTf were separated by ultrafiltration through $10 \mathrm{kDa}$ membrane filters (Millipore, Amicon Ultra-0.5) into low and high molecular mass (LMM and HMM) fractions as described in our former works [22, 61]. Samples contained $20 \mu \mathrm{M}$ complex and $0-33 \mu \mathrm{M}$ apoTf. The concentration of the non-bound complex and ligand in the LMM fractions was determined by UV-vis spectrophotometry by comparing the recorded spectra to those of reference samples without the protein.

Supplementary Information The online version contains supplementary material available at https://doi.org/10.1007/s00775-022-01935-6.

Acknowledgements This work was supported by the ÚNKP-205-SZTE-644 - New National Excellence Program (O.D.), projects FK 124240, PD 131472 and TKP-2021-EGA-32 of the Ministry for Innovation and Technology from the source of the National Research, Development and Innovation Fund.
Author contributions OD: conceptualization, writing—original draft, writing - review and editing, data curation, formal analysis, investigation; BKK: conceptualization, writing-review and editing; ÉAE: conceptualization, writing - review and editing. All authors have read and agreed to the published version of the manuscript.

Funding Open access funding provided by University of Szeged.

\section{Declarations}

Conflict of interest There are no conflicts to declare.

Open Access This article is licensed under a Creative Commons Attribution 4.0 International License, which permits use, sharing, adaptation, distribution and reproduction in any medium or format, as long as you give appropriate credit to the original author(s) and the source, provide a link to the Creative Commons licence, and indicate if changes were made. The images or other third party material in this article are included in the article's Creative Commons licence, unless indicated otherwise in a credit line to the material. If material is not included in the article's Creative Commons licence and your intended use is not permitted by statutory regulation or exceeds the permitted use, you will need to obtain permission directly from the copyright holder. To view a copy of this licence, visit http://creativecommons.org/licenses/by/4.0/.

\section{References}

1. Thakur ML (1977) Gallium-67 and indium-111 radiopharmaceuticals. Int J Appl Rad Isot 28(1-2):183-201. https://doi.org/10. 1016/0020-708x(77)90172-7

2. Dilworth JR, Pascu SI (2014) The radiopharmaceutical chemistry of Gallium(III) and Indium(III) for SPECT imaging. In: Long N, Wong WT (eds) The chemistry of molecular imaging. Wiley, pp 165-178

3. Blower JE, Cooper MS, Imberti C, Ma MT, Marshall C, Young JD, Blower PJ (2019) The radiopharmaceutical chemistry of the radionuclides of gallium and indium. In: Lewis JS, Windhorst $\mathrm{AD}$, Zeglis BM (eds) The radiopharmaceutical chemistry of the radionuclides. Springer, pp 255-271

4. Roca M, Vries EFJ, Jamar F, Israel O, Signore A (2010) Guidelines for the labelling of leucocytes with $111 \mathrm{In}$-oxine. Eur J Nucl Med Mol Imaging 37(4):835-841. https://doi.org/10.1007/ s00259-010-1393-5

5. Loken MK, Clay ME, Carpenter RT, Boudreau RJ, McCullough JJ (1985) Clinical use of indium-111 labeled blood products. Clin Nucl Med 10(12):902-911. https://doi.org/10.1097/00003072198512000-00024

6. Southcott L, Orvig C (2021) Inorganic radiopharmaceutical chemistry of oxine. Dalton Trans 50:16451-16458. https://doi.org/10. 1039/D1DT02685B

7. Savić-Gajić IM, Savić IM (2020) Drug design strategies with metalhydroxyquinoline complexes. Expert Opin Drug Discov 15(3):383-390. https://doi.org/10.1080/17460441.2020.1702964

8. Wang Y-T, Fang Y, Zhao M, Li M-X, Jia Y-M, Han Q-X (2017) $\mathrm{Cu}$ (ii), Ga(iii) and In(iii) complexes of 2-acetylpyridine N(4)phenylthiosemicarbazone: synthesis, spectral characterization and biological activities. Med Chem Commun 8(11):2125-2132. https://doi.org/10.1039/C7MD00415J

9. Merli D, Profumo A, Bloise N, Risi G, Momentè S, Cucca L, Visai L (2018) Indium/gallium maltolate effects on human breast carcinoma cells: in vitro investigation on cytotoxicity and synergism 
with mitoxantrone. ACS Omega 3(4):4631-4640. https://doi.org/ 10.1021/acsomega.7b02026

10. Durmus M, Ahsen V (2010) Water-soluble cationic gallium(III) and indium(III) phthalocyanines for photodynamic therapy. J Inorg Biochem 104(3):297-309. https://doi.org/10.1016/j.jinor gbio.2009.12.011

11. Neagu M, Constantin C, Tampa M, Matei C, Lupu A, Manole E, Ion RM, Fenga C, Tsatsakis AM (2016) Toxicological and efficacy assessment of post-transition metal (Indium) phthalocyanine for photodynamic therapy in neuroblastoma. Oncotarget 7(43):69718-69732. https://doi.org/10.18632/oncotarget.11942

12. Bernstein LR (2005) The use of metals in medicine. In: Gielen M, Tiekink BRT (eds) Metallotherapeutic drugs and metal-based diagnostic agents, vol 14. John Wiley \& Sons, Ltd., pp 259-277

13. Collery P, Keppler BK, Madoulet C, Desoize B (2002) Gallium in cancer treatment. Crit Rev Oncol Hematol 42(3):283-296. https:// doi.org/10.1016/s1040-8428(01)00225-6

14. Bernstein LR, Tanner T, Godfrey C, Noll B (2000) Chemistry and pharmacokinetics of gallium maltolate, a compound with high oral gallium bioavailability. Met Based Drugs 7(1):33-47. https:// doi.org/10.1155/mbd.2000.33

15. Hofheinz RD, Dittrich C, Jakupec MA, Drescher A, Jaehde U, Gneist M, Graf von Keyserlingk N, Keppler BK, Hochhaus A (2005) Early results from a phase I study on orally administered tris(8-quinolinolato)gallium(III) (FFC11, KP46) in patients with solid tumors-a CESAR study (Central European Society for Anticancer Drug Research-EWIV). Int J Clin Pharmacol Ther 43(12):590-591. https://doi.org/10.5414/cpp43590

16. Wilfinger N, Austin S, Scheiber-Mojdehkar B, Berger W, Reipert S, Praschberger M, Paur J, Trondl R, Keppler BK, Zielinski CC, Nowikovsky K (2016) Novel p53-dependent anticancer strategy by targeting iron signaling and BNIP3L-induced mitophagy. Oncotarget 7(2):1242-1261. https://doi.org/10.1863/oncotarget. 6233

17. Chitambar CR (2016) Gallium and its competing roles with iron in biological systems. Biochim Biophys Acta 1863(8):2044-2053. https://doi.org/10.1016/j.bbamcr.2016.04.027

18. Harris WR, Chen Y, Wein K (1994) Equilibrium constants for the binding of indium(III) to human serum transferrin. Inorg Chem 33(22):4991-4998. https://doi.org/10.1021/ic00100a024

19. Benjamín-Rivera JA, Cardona-Rivera AE, Vázquez-Maldonado ÁL, Dones-Lassalle CY, Pabón-Colon HL, Rodríguez-Rivera HM, Rodríguez I, González-Espiet JC, Pazol J, Pérez-Ríos JD, Catala-Torres JF, Rivera MC, Jesus-Soto MG, Cordero-Virella NA, Cruz-Maldonado PM, González-PaganP H-RíosR, Gaur K, Loza-Rosas SA, Tinoco AD (2020) Exploring serum transferrin regulation of nonferric metal therapeutic function and toxicity. Inorganics 8(9):48. https://doi.org/10.3390/inorganics8090048

20. Kojima N, Sugiura Y, Tanaka H (1977) Interaction of albumin, transferrin, and human serum with indium- $113 \mathrm{~m}$ complexes of ethylenediaminetetraacetic acid, penicillamine, and related compounds. Chem Pharm Bull 25(12):3163-3171. https://doi.org/10. $1248 / \mathrm{cpb} .25 .3163$

21. Hnatowich DJ (1977) A review of radiopharmaceutical development with short-lived generator-produced radionuclides other than ${ }^{99 \mathrm{~m}}$ Tc. Int J Appl Rad Isot 28(1-2):169-181. https://doi.org/10. 1016/0020-708X(77)90171-5

22. Enyedy ÉA, Dömötör O, Bali K, Hetényi A, Tuccinardi T, Keppler BK (2015) Interaction of the anticancer gallium(III) complexes of 8-hydroxyquinoline and maltol with human serum proteins. J Biol Inorg Chem 20(1):77-88. https://doi.org/10.1007/ s00775-014-1211-9

23 Harris WR (1998) Binding and transport of nonferrous metals by serum transferrin. Struct Bond 92:121-162. https://doi.org/10. 1007/BFb0081079
24. Otsuki H, Brunetti A, Owens ES, Finn RD, Blasberg RG (1989) Comparison of iron-59, indium-111, and gallium-69 transferrin as a macromolecular tracer of vascular permeability and the transferrin receptor. J Nucl Med 30(10):1676-1685

25. Battistuzzi G, Calzolai L, Messori L, Sola M (1995) Metalinduced conformational heterogeneity of transferrins: a spectroscopic study of indium and other metal-substituted transferrins. Biochem Biophys Res Commun 206(1):161-170. https://doi.org/10.1006/ bbrc.1995.1023

26. Kulprathipanja S, Hnatowich DJ, Beh R, Elmaleh D (1979) Formation constants of gallium- and indium-transferrin. Int J Nucl Med Biol 6(2):138-141. https://doi.org/10.1016/0047-0740(79) 90013-5

27. Clevette DJ, Lyster DM, Nelson WO, Rihela T, Webb GA, Orvig C (1990) Solution chemistry of gallium and indium 3-hydroxy4-pyridinone complexes in vitro and in vivo. Inorg Chem 29(4):667-672. https://doi.org/10.1021/ic00329a021

28. Smith RM, Martell AE (1976) Critical stability constants, inorganic complexes, vol 4. Plenum Press, New York

29. Enyedy ÉA, Dömötör O, Varga E, Kiss T, Trondl R, Hartinger CG, Keppler BK (2012) Comparative solution equilibrium studies of anticancer gallium(III) complexes of 8-hydroxyquinoline and hydroxy(thio)pyrone ligands. J Inorg Biochem 117:189-197. https://doi.org/10.1016/j.jinorgbio.2012.08.005

30. Dömötör O, Pape VFS, May NV, Szakács G, Enyedy ÉA (2017) Comparative solution equilibrium studies of antitumor ruthenium( $\eta 6-p-c y m e n e)$ and rhodium( $\eta 5-\mathrm{C} 5 \mathrm{Me} 5)$ complexes of 8-hydroxyquinolines. Dalton Trans 46(13):4382-4396. https://doi. org/10.1039/C7DT00439G

31. Jakusch T, Gajda-Schrantz K, Adachi Y, Sakurai H, Kiss T, Horváth L (2006) Solution equilibrium characterization of insulinmimetic Zn(II) complexes. J Inorg Biochem 100(9):1521-1526. https://doi.org/10.1016/j.jinorgbio.2006.05.003

32. Farkas E, Kozma E, Kiss T, Toth I, Kurzak B (1995) Role of the $\mathrm{NH}_{3}{ }^{+}$moiety in iron(III)-, aluminium(III)- and gallium(III)-aminohydroxamate interactions. J Chem Soc Dalton Trans 3:477-481. https://doi.org/10.1039/DT9950000477

33 Santos MA, Gama S, Gano L, Cantinhoc G (2004) Farkas E (2004) A new bis(3-hydroxy-4-pyridinone)-IDA derivative as a potential therapeutic chelating agent. Synthesis, metal-complexation and biological assays. Dalton Trans 21:3772-3781. https:// doi.org/10.1039/B409357G

34. Stefanović A, Havel J, Sommer L (1968) On the reaction of iron(III) with maltol. Collect Czech Chem Commun 33(12):41984214. https://doi.org/10.1135/cccc19684198

35. Ramos ML, Justino LLG, Barata R, Costa T, Burrows HD (2021) Complexes of In(III) with 8-hydroxyquinoline-5-sulfonate in solution: structural studies and the effect of cationic surfactants on the photophysical behavior. Dalton Trans 50:16970-16983. https:// doi.org/10.1039/D1DT02858H

36. Alexander OT, Duvenhage MM, Kroon RE, Brink A, Visser HG (2021) Comparison of a dimeric and a monomeric indium-quinolinato complex: synthesis, structure and photoluminescence. New J Chem 45(4):2132-2140. https://doi.org/10.1039/D0NJ03865B

37. Harris WR (1992) Equilibrium model for speciation of aluminium in serum. Clin Chem 38(9):1809-1818. https://doi.org/10.1093/ clinchem/38.9.1809

38. Fanali G, Masi A, Trezza V, Marino M, Fasano M, Ascenzi P (2012) Human serum albumin: from bench to bedside. Mol Aspects Med 33(3):209-290. https://doi.org/10.1016/j.mam.2011. 12.002

39. Zsila F (2013) Subdomain IB is the third major drug binding region of human serum albumin: toward the three-sites model. Mol Pharm 10(5):1668-1682. https://doi.org/10.1021/mp400027q 
40. Bal W, Sokołowska M, Kurowska E, Faller P (2013) Binding of transition metal ions to albumin: sites, affinities and rates. Biochim Biophys Acta 1830(12):444-5455. https://doi.org/10.1016/j. bbagen.2013.06.018

41. Al-Harthi S, Lachowicz JI, Nowakowski ME, Jaremko JML (2019) Towards the functional high-resolution coordination chemistry of blood plasma human serum albumin. J Inorg Biochem 198:110716. https://doi.org/10.1016/j.jinorgbio.2019.110716

42. Bhatnagar DC, Forster LS (1965) The luminescence of oxines and metal oxinates. Spectrochim Acta 21(10):1803-1807. https://doi. org/10.1016/0371-1951\%2865\%2980092-3

43. Zékány L, Nagypál I (1985). In: Leggett DL (ed) Computational methods for the determination of stability constants. Plenum, New York, pp 291-353

44. Lakowicz JR (2006) Principles of fuorescence spectroscopy, 3rd edn. Springer, New York

45. Willis KJ, Szabo AG, Kracjarski DT (1991) Excited-state reaction and the origin of the biexponential fluorescence decay of tryptophan zwitterion. Chem Phys Lett 182(6):614-616. https:// doi.org/10.1016/0009-2614(91)90134-U

46. Vincent JB, Love S (2012) The binding and transport of alternative metals by transferrinBiochim. Biophys Acta Gen Subj 1820(3):362-378. https://doi.org/10.1016/j.bbagen.2011.07.003

47. Harris WR, Messori L (2002) A comparative study of aluminum(III), gallium(III), indium(III), and thallium(III) binding to human serum transferrin. Coord Chem Rev 228(2):237-262. https://doi.org/10.1016/S0010-8545(02)00037-1

48. Macgillivray RTA, Mendez E, Sinha SK, Sutton MR, LinebackZins J, Brew K (1982) The complete amino acid sequence of human serum transferrin. Proc Natl Acad Sci USA 79(8):25042508. https://doi.org/10.1073/pnas.79.8.2504

49. Pape VSF, May NV, Gál TG, Szatmári I, Szeri F, Fülöp F, Szakács G, Enyedy ÉA (2018) Impact of copper and iron binding properties on the anticancer activity of 8-hydroxyquinoline derived Mannich bases. Dalton Trans 47:17032-17045. https://doi.org/ 10.1039/C8DT03088J

50. Cipurković A, Horozić E, Marić S, Mekić L, Junuzović H (2021) Metal complexes with 8-hydroxyquinoline: synthesis and in vitro antimicrobial activity. Open J Appl Sci 11:1-10. https://doi.org/ 10.4236/ojapps.2021.111001

51. Steger HF, Corsini A (1973) Stability of metal oxinates-I, effect of ligand basicity. J Inorg Nucl Chem 35(5):1621-1636. https:// doi.org/10.1016/0022-1902(73)80253-2
52. Quentel F, Cabon JY, L'Her M, Courtot-Coupez J (1978) Stabilite de complexes organometalliques dans le carbonate de propylene sature d'eau: complexes Hydroxy-8 quinoléine-Cuivre(II), Cadmium(II), Zinc(II) et Plomb(II). Anal Chim Acta 96(1):133142. https://doi.org/10.1016/S0003-2670(01)93405-1

53. Martell AE (2013) Metal complexes in aqueous solutions. Springer-Verlag, New York

54. Mills CF (1989) Zinc in human biology. Springer-Verlag, New York

55. Beaven GH, Chen S, d' Albis A, Gratzer WB (1974) A spectroscopic study of the haemin-human-serum-albumin system. Eur J Biochem 41(3):539-546. https://doi.org/10.1111/j.1432-1033. 1974.tb03295.x

56. Luk CK (1971) Study of the nature of the metal-binding sites and estimate of the distance between the metal-binding sites in transferrin using trivalent lanthanide ions as fluorescent probes. Biochem 10(15):2838-2843. https://doi.org/10.1021/bi00791a006

57 James NG, Mason AB (2008) Protocol to determine accurate absorption coefficients for iron containing transferrins. Anal Biochem 378(2):202-207. https://doi.org/10.1016/j.ab.2008.04.012

58. Irving HM, Miles MG, Pettit LD (1967) A study of some problems in determining. Anal Chim Acta 38:475-488. https://doi.org/ 10.1016/S0003-2670(01)80616-4

59. SCQuery (1993-2005) The IUPAC Stability Constants Database. Academic Software (Version 5.5), Royal Society of Chemistry.

60 Gans P, Sabatini A, Vacca A (1966) Investigation of equilibria in solution. Determination of equilibrium constants with the HYPERQUAD suite of programs. Talanta 43(10):1739-1753. https://doi.org/10.1016/0039-9140(96)01958-3

61. Dömötör O, Hartinger CG, Bytzek AK, Kiss T, Keppler BK, Enyedy ÉA (2013) Characterization of the binding sites of the anticancer ruthenium(III) complexes KP1019 and KP1339 on human serum albumin via competition studies. J Biol Inorg Chem 18(1):9-17. https://doi.org/10.1007/s00775-012-0944-6

Publisher's Note Springer Nature remains neutral with regard to jurisdictional claims in published maps and institutional affiliations.

\section{Authors and Affiliations}

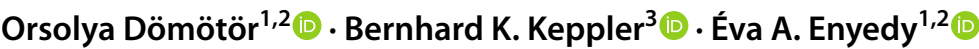

1 Department of Inorganic and Analytical Chemistry, Interdisciplinary Excellence Centre, University of Szeged, Dóm tér 7, 6720 Szeged, Hungary

2 MTA-SZTE Lendület Functional Metal Complexes Research Group, University of Szeged, Dóm tér 7, 6720 Szeged, Hungary
3 Institute of Inorganic Chemistry and Research Cluster 'Translational Cancer Therapy Research', University of Vienna, Währinger Straße, 42, Vienna, Austria 